\title{
Water Cycle Algorithm for Probabilistic Planning of Renewable Energy Resource, Considering Different Load Models
}

\author{
Ayat Ali Saleh ${ }^{1}$, Tomonobu Senjyu ${ }^{2}$, Salem Alkhalaf ${ }^{3} \mathbb{D}$, Majed A. Alotaibi ${ }^{4}$ \\ and Ashraf M. Hemeida $1, *$ (D) \\ 1 Electrical Engineering Department, Faculty of Energy Engineering, Aswan University, Aswan 81528, Egypt; \\ eng_ayat87@yahoo.com \\ 2 Department of Electrical and Electronics Engineering, Faculty of Engineering, University of the Ryukyus, \\ Nakagami, Okinawa 903-0213, Japan; a985542@yahoo.co.jp \\ 3 Department of Computer, College of Science and Arts in Ar-Rass, Qassim University, \\ Ar-Rass 51921, Saudi Arabia; s.alkhalaf@qu.edu.sa \\ 4 Department of Electrical Engineering, College of Engineering, King Saud University, \\ Riyadh 11421, Saudi Arabia; majedalotaibi@ksu.edu.sa \\ * Correspondence: ashraf@aswu.edu.eg
}

Received: 13 October 2020; Accepted: 2 November 2020; Published: 5 November 2020

check for updates

\begin{abstract}
This work introduces multi-objective water cycle algorithm (MOWCA) to find the accurate location and size of distributed energy resource (DERs) considering different load models for two seasons (winter, and summer). The impact of uncertainties produced from load and renewable energy resource (RES) such as wind turbine (WT) and photovoltaic (PV) on the performance of the radial distribution system (RDS) are covered as this is closer to the real operation condition. The point estimate method (PEM) is applied for modeling the RES uncertainties. An optimization technique is implemented to find the multi-objective optimal allocation of RESs in RDSs considering uncertainty effect. The main objectives of the work are to maximize the technical, economic and environmental benefits by minimizing different objective functions such as the dissipated power, the voltage deviation, DG cost and total emissions. The proposed multi-objective model is solved by using multi-objective water cycle algorithm (MOWCA), considering the Pareto criterion with nonlinear sorting based on fuzzy mechanism. The proposed algorithm is carried out on different IEEE power systems with various cases.
\end{abstract}

Keywords: uncertainty effect; multi-objective water cycle algorithm (MOWCA); power loss reduction; voltage deviation; cost; pollutant gas emissions; renewable energy source

\section{Introduction}

Nowadays, the global load demand for electricity has been greatly increased [1]. This leads to increasing the distribution system capacity by installing new distributed energy resources, therefore installing distributed energy resources (DERs) is an urgent matter. DERs have become an essential electric devices that integrated with modern distributed systems. Optimum place, capacity and number of needed DERs for accurate behavior of distribution systems are essential for ensuring optimum operating performance. The selection criteria of the DERs source is very important to ensure providing the advantages of integrating them with radial networks [1].

Nowadays, introducing the hybrid renewable energy sources to be integrated with radial networks providing technical and economic impacts. Hybrid renewable energy systems based on photovoltaic and wind energy systems are used extensively and have long lifetime. The integration of hybrid 
energy resources with radial distribution networks adding many benefits, such as improving the radial network performance, and more economic in addition to decreasing power dissipated than integration of wind (WT) and (PV) energy resources individually [1,2]. Renewable energy systems, such as PV and WT system can decrease carbon emissions and supply clean energy, but may not capable to cover the needed energy for load requirements in a continuous form due to sudden changes in weather, which leads to reducing the energy output of both PV and WT systems.

There are different configurations of solar power systems such as on-grid, off-grid, and hybrid-grid. In on-grid systems, batteries is not required and use either solar inverters or micro-inverters, which enables the source to be connected with the public electricity grid and widely used by homes and businesses. These systems are not able to generate electricity during a blackout due to safety reasons. In off-grid systems, the PV systems are not connected to the electricity grid and therefore require battery storage. Hybrid systems contain both solar and battery storage, which operated in standalone mode and provide power to the loads during grid-side faults or during maintenance on the grid side [3].

Many optimization techniques have been employed to deal with the problem of DERs optimal allocation to maximize their benefits [4,5]. The main different between these optimization techniques are the objectives functions, the control variables, and the assumptions. Optimization objectives can be achieved in single or multi-objective spaces. In practice, multi-objective optimization became a very important decision-making tool rather than the single objective optimization, due to it capability of providing a set of non-dominated solutions $[1,6]$.

No doubt that the DERs are participate in strengthen the distribution grid networks, and evaluate many factors based on the bio-inspired optimization techniques. This leads to many advantages that can improve the distribution grid network behavior $[7,8]$.

The electric power system has several load models, such as constant, residential, commercial, and industrial loads, the reactive and real power demands values at various load models dependence on their operating voltage profile [9-13]. This article studies the systems under different load models.

The computational fluid dynamics (CFD) was used extensively to discuss the uncertainty inherent to renewable energy sources such as wind turbines [14] and wind farms [15]. The CFD was implemented to optimum design for such renewable energy sources such as wind energy system and or wind farms. The CFD provides more uncertainty to the final design of wind turbine, as well as wind farm [16]. The implementation of CFD simulations provide variability in the wind energy system operating performance [17].

This article presents application of (MOWCA), to find the optimal location and capacity of DESs for reducing total network dissipated energy losses, cost, voltage deviation, and emission with different load models. The uncertainties effects produced from renewable energy resource and load are considered in this paper. The point estimate method (PEM) is implemented for modeling the solar, and wind power uncertainties. Robust Optimization is applied for modeling the load uncertainties. The MOWCA is applied to find a representative set of the Pareto accurate solutions for the three objective functions. Therefore, a fuzzy clustering approach is integrated with the suggested technique to choose the best and accurate solution from the Pareto front. The performance of study system is analyzed under three values of standard deviation.

The following are the points represent the work contributions:

i. Impact of uncertainties produced from a renewable energy resource, such as (solar, and wind power generation source) and load on the performance of the network is covered.

ii. New electric resources with suitable size, placement, and type are integrated.

iii. The optimal placement and capacity of DESs is obtained by multi-objective water cycle algorithm (MOWCA).

iv. The effect of different values of standard deviation on the network performance is covered.

v. Various load configurations, such as (constant, residential, industrial, commercial, and agricultural) in winter and summer are considered. 
i. The technique guarantees satisfactory solution for all possible operating conditions.

ii. The point estimate method (PEM) is utilized for modeling the solar and (WT) uncertainties.

iii. The different objective functions such as total power loss, voltage deviation and, cost, and emission are used.

The rest of this paper is ordered as follows: Section 2, presents previous work, Section 3 provides the problem formulation. Section 4, introduces the mathematical model of the DERs. Different loading models were displayed in Section 5. Load uncertainty is presented in Section 6. The pest estimation method is discussed in Section 7. Section 8, introduces the mathematical model of the proposed technique. The results and discussions of applying the suggested technique in different cases displays in Section 9. The conclusion of the paper is given in Section 10.

\section{Previous Work}

A review of the applied techniques for the optimal allocation of DERs in RDS is depicted in Table 1.

Table 1. The summaries of published applied techniques.

\begin{tabular}{|c|c|c|c|c|c|c|c|c|c|c|}
\hline \multirow{2}{*}{ Reference } & \multirow{2}{*}{ Optimization Algorithms } & \multirow{2}{*}{$\begin{array}{l}\text { IEEE Bus } \\
\text { System }\end{array}$} & \multirow{2}{*}{$\begin{array}{l}\text { Load } \\
\text { Model }\end{array}$} & \multicolumn{2}{|c|}{ RES } & \multicolumn{2}{|c|}{ N-RES } & \multicolumn{3}{|c|}{ Uncertainty Source } \\
\hline & & & & PV & WT & FC & MT & PV & WT & Load \\
\hline [18] & $\begin{array}{l}\text { Multi-Objective Antlion } \\
\text { Optimisation (MALO). } \\
\text { Multi-Objective Natural }\end{array}$ & 33-bus & & \multicolumn{2}{|c|}{ bio-mass } & $\checkmark$ & & \multicolumn{2}{|c|}{ bio-mass } & $\checkmark$ \\
\hline [19] & $\begin{array}{l}\text { Aggregation Algorithm } \\
\text { (MONAA). }\end{array}$ & 25- node & & $\checkmark$ & $\checkmark$ & & & $\checkmark$ & $\checkmark$ & \\
\hline [20] & Greedy Search Algorithm (GSA) & 28-bus & $\checkmark$ & & & & & & & \\
\hline [21] & Firefly Algorithm (FA) & 69-bus & $\checkmark$ & $\checkmark$ & & & & & & \\
\hline [22] & $\begin{array}{l}\text { bat optimization } \\
\text { algorithm (BOA) }\end{array}$ & 33-bus & $\checkmark$ & $\checkmark$ & & $\checkmark$ & & & & \\
\hline [23] & $\begin{array}{c}\text { Multi-objective } \\
\text { chaotic symbiotic organisms } \\
\text { search (MOCSOS) }\end{array}$ & 33, 69-bus & $\checkmark$ & & & & & & & \\
\hline [24] & Improved bee algorithm (IBA) & 37, 123-bus & $\checkmark$ & $\checkmark$ & $\checkmark$ & & & $\checkmark$ & $\checkmark$ & \\
\hline [25] & $\begin{array}{l}\text { Mixed integer conic } \\
\text { programming (MICP) }\end{array}$ & 69-Bus & & $\checkmark$ & $\checkmark$ & GT & & $\checkmark$ & $\checkmark$ & \\
\hline [26] & $\begin{array}{l}\text { Multi-objective crow } \\
\text { search algorithm }\end{array}$ & & & $\checkmark$ & & $\checkmark$ & DG & $\checkmark$ & & $\checkmark$ \\
\hline [27] & $\begin{array}{l}\text { Craziness-based particle swarm } \\
\text { optimization (CRPSO) algorithm }\end{array}$ & 33-bus & & $\checkmark$ & $\checkmark$ & & & $\checkmark$ & $\checkmark$ & \\
\hline [28] & $\begin{array}{l}\text { Cuckoo search algorithm (CSA) } \\
\text { and Flower pollination } \\
\text { algorithm (FPA). }\end{array}$ & 57-bus & & $\checkmark$ & $\checkmark$ & & & $\checkmark$ & $\checkmark$ & \\
\hline [29] & $\begin{array}{l}\text { Whale optimization } \\
\text { algorithm (WOA) }\end{array}$ & $\begin{array}{l}15,33,69,85 \\
118 \text {-bus }\end{array}$ & & $\checkmark$ & $\checkmark$ & & & & & \\
\hline [30] & Differential Evolution (DE) & 57-bus & & $\checkmark$ & $\checkmark$ & & & & & \\
\hline [31] & $\begin{array}{l}\text { Multi objective particle swarm } \\
\text { optimization }\end{array}$ & 33-bus & & $\checkmark$ & $\checkmark$ & & & $\checkmark$ & $\checkmark$ & \\
\hline [32] & $\begin{array}{l}\text { Non-dominated sorting genetic } \\
\text { algorithm (NSGA) }\end{array}$ & 37-bus & & $\checkmark$ & $\checkmark$ & & & $\checkmark$ & $\checkmark$ & \\
\hline [33] & $\begin{array}{l}\text { Multi-objective water cycle } \\
\text { algorithm (MOWCA) }\end{array}$ & 119-bus & $\checkmark$ & $\checkmark$ & $\checkmark$ & $\checkmark$ & $\checkmark$ & $\checkmark$ & $\checkmark$ & $\checkmark$ \\
\hline
\end{tabular}

\section{Problem Formulation}

\subsection{Minimization of Power Losses $\left(P_{\text {loss }}\right)$}

Integration of DESs at suitable location and capacity leads to minimization of network power loss. The loss calculation is demonstrated below [29]:

$$
i_{p q}=\frac{V_{P}-V_{q}}{r_{k}+j x_{k}} \quad i_{q p}=\frac{V_{q}-V_{p}}{r_{k}+j x_{k}}
$$


where $p$, and $q=$ to bus and from bus for kth line; $V_{p}$ and $V_{q}=$ to bus and from bus complex voltage (pu); $r_{k}$ is the resistance of $k$ th line $(\mathrm{pu})$; and $x_{k}$ is the reactance of kth line $(\mathrm{pu})$.

$$
S_{p q}=V_{p} \times i_{p q}{ }^{*} \quad S_{q p}=V_{q} \times i_{q p}{ }^{*}
$$

$S_{p q}$ is the complex power flow from bus $\mathrm{p}$ to bus $\mathrm{q}$ through kth line. $S_{q p}$ is the complex power flow from bus $q$ to bus $\mathrm{p}$ through kth line.

$$
\begin{gathered}
\text { Total loss }=\sum_{k=1}^{n \text { line }} S_{p q}-S_{q p} \\
P_{\text {loss }}=\text { Real (Total loss), } \\
Q_{\text {loss }}=\text { Imaginary (Total loss) }
\end{gathered}
$$

\subsection{Minimization of Voltage Deviation (VD)}

The voltage deviation is decreased after the installation of DG with optimal allocation. The voltage deviation (VD) of any of the studies system bus is evaluated related to substation bus that still has 1-pu voltage. It is calculated as given in Equation (6). Here, $V_{n j}$ refers to the substation voltage for kth line [34].

$$
\mathrm{VD}=\sum_{n j=1}^{N b}\left|V_{n j}-1\right|
$$

The objective function for decreasing power dissipated and voltage deviation is formulated as follows:

$$
F_{1}=0.6 \times P_{\text {loss }}+0.4 \times V D
$$

\subsection{Minimization of Cost}

A best dispatch problem requires achieving system loads in the most economical manner possible. The total expense is the total buying force cost of the main substation and DES, which can be calculated from the following [35]:

$$
F_{3}=\cos t=\operatorname{Cost}_{\text {grid }}+\sum_{i=1}^{N_{D E R s}} C_{D E R s, i}
$$

The total buying force cost of the main substation as follows:

$$
\text { Cost }_{\text {grid }}=P_{\text {grid }} \cdot \pi_{\text {grid }}
$$

The cost of a DES encompasses its fixed cost and a variable cost can be formulated by:

$$
C_{D E R s, i}=\operatorname{Cost}_{D E R s i}^{F X}+\operatorname{Cost}_{D E R s, i} \cdot P_{D E R s, i}
$$

From the last equation, the DERs expense includes its initial cost term and a variable term.

$\operatorname{Cost}_{\mathrm{DERs}, \mathrm{i}}^{\mathrm{FX}}$ is initial investment (or fixed) cost, which includes the cost of equipment, infrastructure, commissioning, as follows:

$$
\operatorname{Cost}_{D E R s, i}^{F X}=\frac{C_{c a p, i} \cdot P_{c a p, i} . r b}{T \times 365 \times 24 \times K_{D E R s, i}}
$$

where Cost $_{D E R s, i}$ is variable cost associated with operation and maintenance (O\&M) as well as fuel, which can be formulated as:

$$
\operatorname{Cost}_{D E R s, i}=C_{O \& M, i}+C_{F, i}
$$

The suggested (DERs) technologies are shown in Table 2. 
Table 2. The suggested (DERs) technologies.

\begin{tabular}{ccccccc}
\hline Generation & $\begin{array}{c}\text { Capacity } \\
\mathbf{( k W )}\end{array}$ & $\begin{array}{c}\text { Capacity } \\
\text { Factor }\end{array}$ & $\begin{array}{c}\text { Life Time } \\
\mathbf{( Y e a r )}\end{array}$ & $\begin{array}{c}\text { Capital Cost } \\
\mathbf{( \$ / \mathbf { k } )}\end{array}$ & $\begin{array}{c}\text { Maintenance } \\
\text { Cost } \mathbf{( \$ \mathbf { k W h } )}\end{array}$ & $\begin{array}{c}\text { Annual } \\
\text { Conversion Factor }\end{array}$ \\
\hline FC & 400 & 0.4 & 10 & 3674 & 0.001 & 0.1006 \\
MT & 250 & 1 & 10 & 750 & 0.039 & 0.2152 \\
PV & 300 & 0.25 & 20 & 6675 & 0.005 & 0.0543 \\
WT & 300 & 0.2 & 20 & 1500 & 0.005 & 0.1006 \\
\hline
\end{tabular}

\subsection{Minimization of Emission}

In this objective, decreasing of emissions created from various electric sources and grid is the goal. The following gases are considered, i.e., carbon dioxide $\left(\mathrm{CO}_{2}\right)$, nitrogen oxides $\left(\mathrm{NO}_{\mathrm{x}}\right)$ and sulfur dioxide $\left(\mathrm{SO}_{2}\right)$. The Grid, and the DER data is given in Table 3. The values of emission coefficients of DES units and the grid are represented as follows [36]:

$$
\mathrm{F}_{4}=\sum_{\mathrm{i}=1}^{\mathrm{N}_{\mathrm{MT}}} \mathrm{E}_{\mathrm{MTi}}+\sum_{\mathrm{i}=1}^{\mathrm{N}_{\mathrm{FC}}} \mathrm{E}_{\mathrm{FCi}}+\sum_{\mathrm{i}=1}^{\mathrm{N}_{\mathrm{WT}}} \mathrm{E}_{\mathrm{WTi}}+\sum_{\mathrm{i}=1}^{\mathrm{N}_{\mathrm{PV}}} \mathrm{E}_{\mathrm{PVi}}+\mathrm{E}_{\mathrm{Grid}}
$$

Table 3. Emission related for resources.

\begin{tabular}{cccccc}
\hline \multirow{2}{*}{ Emission Type } & \multicolumn{5}{c}{ Emission Factors (lb/MW h) } \\
\cline { 2 - 6 } & Grid & MT & FC & WT & PV \\
\hline $\mathrm{NO}_{\mathbf{X}}$ & 5.06 & 0.4 & 0.03 & 0 & 0 \\
$\mathrm{SO}_{2}$ & 11.6 & 0.008 & 0.006 & 0 & 0 \\
$\mathrm{CO}_{2}$ & 2031 & 1596 & 1078 & 0 & 0 \\
\hline
\end{tabular}

The emission produced from MT $\left(\mathrm{E}_{\mathrm{MTi}}\right.$, ) can be calculated by the following equation:

$$
\mathrm{E}_{\mathrm{MTi}}=\left(\mathrm{CO}_{2}^{\mathrm{MT}}+\mathrm{NO}_{\mathrm{x}}^{\mathrm{MT}}+\mathrm{SO}_{2}^{\mathrm{MT}}\right) \times \mathrm{P}_{\mathrm{MTi}}
$$

The emission produced from FC $\left(\mathrm{E}_{\mathrm{FCi}}\right.$, ) can be formulated by:

$$
\mathrm{E}_{\mathrm{FCi}}=\left(\mathrm{CO}_{2}^{\mathrm{FC}}+\mathrm{NO}_{\mathrm{x}}^{\mathrm{FC}}+\mathrm{SO}_{2}^{\mathrm{FC}}\right) \times \mathrm{P}_{\mathrm{FCi}}
$$

The emission produced from WT $\left(\mathrm{E}_{\mathrm{WTi}}\right)$ can be expressed as follows:

$$
\mathrm{E}_{\mathrm{WTi}}=\left(\mathrm{CO}_{2}^{\mathrm{WT}}+\mathrm{NO}_{\mathrm{x}}^{\mathrm{WT}}+\mathrm{SO}_{2}^{\mathrm{WT}}\right) \times \mathrm{P}_{\mathrm{WTi}}
$$

The emission produced from $\mathrm{PV}\left(\mathrm{E}_{\mathrm{PVi}}\right)$ is formulated as follows:

$$
\mathrm{E}_{\mathrm{PVi}}=\left(\mathrm{CO}_{2}^{\mathrm{PV}}+\mathrm{NO}_{\mathrm{x}}^{\mathrm{PV}}+\mathrm{SO}_{2}^{\mathrm{PV}}\right) \times \mathrm{P}_{\mathrm{PVi}}
$$

The emission produced from grid $\left(\mathrm{E}_{\mathrm{Grid}}\right)$ can be calculated using the following equation:

$$
\mathrm{E}_{\mathrm{Grid}}=\left(\mathrm{CO}_{2}^{\text {Grid }}+\mathrm{NO}_{\mathrm{x}}^{\text {Grid }}+\mathrm{SO}_{2}^{\text {Grid }}\right) \times \mathrm{P}_{\text {Gridi }}
$$

\subsection{Constraints}

The active and reactive power supplied by DES, and bus voltages are examples of operational constraints needed to achieve them while finding the best DES position. 


\subsubsection{Power Balanced Constraints}

In these limitations, the total power flow through the distribution system coming from DGs and grid must be equivalent to the total power flow going to load and loss of the system, as follows.

$$
\begin{gathered}
\sum_{n j=1}^{n b} p_{\text {gnj }}+p_{\text {grid }}=\sum_{n j=1}^{n b} p_{d n j}+p_{\text {loss }} \\
\sum_{n j=1}^{n b} Q_{\text {gnj }}+Q_{\text {grid }}=\sum_{n j=1}^{n b} Q_{d n j}+Q_{\text {loss }}
\end{gathered}
$$

\subsubsection{Inequality Constraints}

Nonrenewable Generation limit: The upper and lower constrains of powers supplied by DES are calculated using the following equation:

$$
\begin{gathered}
P_{g n j}^{\min } \leq P_{g n j} \leq P_{g n j}^{\max } \\
Q_{g n j}^{m i n} \leq Q_{g n j} \leq Q_{g n j}^{m a x}
\end{gathered}
$$

Voltage limit: the buses' voltage limitation is shown as follows:

$$
V_{i}^{\min } \leq \mathrm{V}_{i} \leq V_{i}^{\max }
$$

Line thermal limits: The complex power through any line is limited by its rated value as follows:

$$
S_{i j} \leq S_{i j}^{M a x}
$$

\section{DERs Modeling}

In this work, the DERs devices are modeled as RESs and N-RESs. The control of PV and WT in this study is adjusted to operate at unity PF.

\subsection{Photovoltaic System (PVS)}

In this section, the probabilistic modelling of photovoltaic system in RDS is presented. Sunlight is converted into electrical energy by a photovoltaic generator. The main parameter that affects the amount of power output from this generator is the amount of solar radiation. To model the behavior of solar irradiance, assume the irradiance of the solar irradiance performance $\beta$ PDF and CDF are implemented to represent it according to (25) and (26) [37]:

$$
\begin{gathered}
f_{B}\left(s_{i}\right)=\left\{\begin{array}{c}
\frac{\Gamma(\alpha+\beta)}{\Gamma(\alpha) \Gamma(\beta)} \cdot s_{i}{ }^{(\alpha-1)}\left(1-s_{i}\right)^{(\beta-1)} \text { for } 0 \leq s_{i} \leq 1, \alpha \geq 0, \beta \geq 0 \\
0 \text { otherwise }
\end{array}\right. \\
F_{B}\left(s_{i}\right)=\int_{0}^{s i} \frac{\Gamma(\alpha+\beta)}{\Gamma(\alpha) \Gamma(\beta)} \cdot s_{i}^{(\alpha-1)}\left(1-s_{i}\right)^{(\beta-1)} d s i
\end{gathered}
$$

where $\alpha$ and $\beta$ are the parameters of beta PDF presented as follows:

$$
\begin{gathered}
\alpha=\mu\left(\frac{\mu(1+\mu)}{\sigma^{2}}-1\right) \\
\beta=(1-\mu)\left(\frac{\mu(1+\mu)}{\sigma^{2}}-1\right)
\end{gathered}
$$


The relationship between solar irradiance and solar power is expressed as follows:

$$
P_{p v}\left(s_{i}\right)=A_{c} \cdot \eta \cdot s_{i}
$$

when applying Equation (21) the probability density function $\mathrm{f}_{\mathrm{P}_{\mathrm{pv}}}\left(\mathrm{P}_{\mathrm{pv}}\right)$ for the output power of PVs can be obtained as the following equation:

$$
f_{P_{p v}}\left(P_{p v}\right)=\left\{\begin{array}{c}
\frac{\Gamma(\alpha+\beta)}{\Gamma(\alpha) \Gamma(\beta)} \cdot\left(A_{c} \cdot \eta \cdot s_{i}\right)^{(\alpha-1)}\left(1-A_{c} \cdot \eta \cdot s_{i}\right)^{(\beta-1)} \\
0 \text { if } P_{p v} \in\left[0, P_{p v}(s i)\right] \\
0 \text { otherwise }
\end{array}\right.
$$

\subsection{Wind Energy System (WES)}

The wind energy is converted into electric power by wind turbines (WT). The factors affecting the power generated from a wind turbine are accessibility and speed of wind, the power curve of wind turbines, and size and shape of the turbine. The output power produced by WT is calculated as a function of wind speed $v_{\text {wind }}$ according to the following equation: [1]:

$$
P_{w}\left(V_{\text {wind }}\right)=\left\{\begin{array}{c}
0 v_{\text {wind }}<v_{c i} \text { or } v_{c o} \leq v_{\text {wind }} \\
p_{R} \cdot \frac{\left(v_{\text {wind }}-v_{c i}\right)}{\left(v_{r}-v_{c i}\right)} v_{c i} \leq v_{\text {wind }}<v_{r} \\
p_{R} \quad v_{r} \leq v_{\text {wind }}<v_{c o}
\end{array}\right.
$$

The probability density function $\mathrm{f}_{\mathrm{pw}}\left(\mathrm{P}_{\mathrm{w}}\right)$ for the power generated by WES is expressed as follows:

$$
f_{p w}\left(P_{w}\right)\left\{\begin{array}{c}
1-\left[F_{v}\left(v_{c o}\right)-F_{v}\left(v_{c i}\right)\right] p_{w}=0 \\
\left(\frac{\left(v_{r}-v_{c i}\right)}{p_{R}}\right)\left(\frac{\pi}{2 V_{m}^{2}}\right) \times\left(v_{c i}+\left(v_{r}-v_{c i}\right) \cdot \frac{p_{w}}{p_{R}}\right) \times \exp \left[-\left(\frac{v_{c i}+\left(v_{r}-v_{c i}\right) \cdot \frac{p_{w}}{p_{R}}}{\frac{2}{\sqrt{\pi}} V_{m}}\right)^{2}\right] 0<p_{w}<p_{R} \\
F_{v}\left(v_{c o}\right)-F_{v}\left(v_{r}\right) p_{w}=p_{R}
\end{array}\right.
$$

\subsection{Full Cell Unit (FC)}

The electric power output of FC units is described as follows [1]:

$$
C_{F C}=C_{g a s F C} \times \frac{P_{F C}}{\eta_{F C}}
$$

\subsection{Micro Turbine Unit (MT)}

The electric power output of MT units is obtained from the following equation: [1]:

$$
C_{M T}=C_{g a s M T} \times \frac{P_{M T}}{\eta_{M T}}
$$

\section{Load Model}

In this study, five different types of loads are considered. The considered load types are constant, residential, commercial, Industrial, and agricultural load type. The real and complex power of the load is considered as constant power in the classical load flow problems, despite, the load may be nonlinear such as residential, commercial, Industrial, and agricultural which discussed by models in [23]. The effect of different types of loads is represented by exponential function as the following form:

$$
\begin{gathered}
P_{i}=P_{o i} V_{i}^{\alpha} \\
Q_{i}=Q_{o i} V_{i}^{\beta}
\end{gathered}
$$

The values of $\alpha$ and $\beta$ for different types of load models in winter and summer are listed in Table 4 [22]. 
Table 4. The exponent values for various load models.

\begin{tabular}{ccccccccccc}
\hline Load Type & \multicolumn{2}{c}{ Constant } & \multicolumn{2}{c}{ Residential } & \multicolumn{2}{c}{ Commercial } & \multicolumn{2}{c}{ Industrial } & \multicolumn{2}{c}{ Agricultural } \\
\hline & $\propto$ & $\beta$ & $\alpha$ & $\beta$ & $\alpha$ & $\beta$ & $\alpha$ & $\beta$ & $\propto$ & $\beta$ \\
\hline Summer & 0 & 0 & 0.9 & 2.9 & 0.7 & 2.5 & 0.1 & 0.6 & 1.4 & 1.4 \\
Winter & 0 & 0 & 1.5 & 2.8 & 0.8 & 2.4 & 0.1 & 0.6 & 1.4 & 1.4 \\
\hline
\end{tabular}

\section{Load Uncertainties Model}

To enhance the flexibility and robustness of the proposed system planning and providing reliability to the analysis, the commonly used normal distribution is adopted to approximately characterize the uncertainty of load. The random active power $\left(\mathrm{P}_{\mathrm{d}}\right)$ of load $\mathrm{i}$ are generated based on the probability density function of the load power, $\mathrm{f}\left(\mathrm{P}_{\mathrm{di}}\right)$ according to the following equation: [38]:

$$
f\left(P_{d i}\right)=\frac{1}{\sqrt{2 \pi \sigma_{P_{d}^{i}}^{2}}} \exp \left[-\frac{\left(P_{d i}-\mu_{P_{d}^{i}}\right)^{2}}{2 \sigma_{P_{d}^{i}}^{2}}\right]
$$

where the standard deviation $\left(\sigma_{\mathrm{P}_{\mathrm{d}}}\right)$ of normal distribution is taken $10 \%$ of the considered load level with zero mean $\left(\mu_{P_{d}}\right)$ value [39]. Therefore, the uncertainty of power demand prediction is modeled by a vector of independent Gaussian random variables, which is represented as an addition injection at each selected load bus.

\section{Model of Uncertainties Based on PEM Method}

Point estimate method (PEM) is one of the appropriate tools to deal with uncertainties. Details of this method are discussed in [38-40]. In this article, $(2 m+1)$ Hong's PEM scheme [40] is employed to three buses in each distribution network to represent the load uncertainty. In each case study, the optimization methods performed $(2 \times 3+1)$ load-flow calculations to estimate the solution of the load-flow based on the PEM method, where three uncertain system parameters are considered in each test system. General steps of (PEM):

Step 1: The statistical information of the input variables is calculated.

Step 2: The concentrations for each input variables are determined.

Step 3: The $\mathrm{F}$ function at the points $\left(\mathrm{p}_{1} ; \mathrm{p}_{2} ; \ldots ; \mathrm{X}_{1, \mathrm{k}} ; \ldots ; \mathrm{p}_{\mathrm{m}-1} ; \mathrm{p}_{\mathrm{m}}\right)$ are evaluated by the weighted probability factor, where $p_{1}$ is the mean value of the input variable $X_{1}$. The points $\left(\mathrm{p}_{1} ; \mathrm{p}_{2} ; \ldots ; \mathrm{x}_{1, \mathrm{k}} ; \ldots ; \mathrm{p}_{\mathrm{m}-1} ; \mathrm{p}_{\mathrm{m}}\right)$ includethe $\mathrm{kth}$ location $\mathrm{X}_{1, \mathrm{k}}$ and the mean value of $\mathrm{m}-1$ remaining input variables $\left(\mathrm{p}_{1} ; \mathrm{p}_{2} ; \ldots ; \mathrm{p}_{l-1} ; \mathrm{p}_{l+1} ; \mathrm{p}_{\mathrm{m}-1} ; \mathrm{p}_{\mathrm{m}}\right)$.

Step 4: The statistical information of the output variable $(Z)$ are calculated by using:

$$
\mathrm{F}\left(\mathrm{Z}=\mathrm{F}\left(\mathrm{p}_{1} ; \mathrm{p}_{2} ; \ldots ; \mathrm{p}_{1} ; \ldots ; \mathrm{p}_{\mathrm{m}} ; \mathrm{c}\right)\right)
$$

Step 5: For each random variable $\mathrm{p}_{1}$, the three locations are Computed using mean value $\left(\mu_{p l}\right)$ and variance value $\left(\sigma_{p l}\right)$ of $\mathrm{p}_{1}$.

$$
p_{l k}=\mu_{p l}+\varepsilon_{l k} \sigma_{p l} \quad k=1,2,3
$$

Step 6: The standard location, weighting factor $\mathrm{w}_{\mathrm{lk}}$ of the uncertain parameters can be find by the following equations:

$$
\begin{gathered}
\varepsilon_{l k}=\frac{\lambda_{13}}{2}+(-1)^{3-k} \sqrt{\lambda_{13}-\frac{3 \lambda_{14}^{2}}{4}} \quad k=1,2 \varepsilon_{l 3}=0 \\
w_{l k}=\frac{(-1)^{3-k}}{\varepsilon_{l k}\left(\varepsilon_{l 1}-\varepsilon_{l 2}\right)}, w_{l 3}=\frac{1}{m}-\frac{1}{\lambda_{14}-\lambda_{13}^{2}} \quad k=1,2 \varepsilon_{l 3}=0
\end{gathered}
$$


Step 7: The F function at this point and its new weighting factor $\left(\mathrm{w}_{0}\right)$ will be calculated as follows:

$$
w_{0}=\sum_{l=1}^{m} w_{13}=1-\sum_{l=1}^{m} \frac{1}{\lambda_{14}-\lambda_{13}^{2}}
$$

In this work, $\left(\mathrm{K}=3, \varepsilon_{l k}=0\right)$ is used for modeling PV and WT output power under the effect of uncertainties. After calculating two pairs of locations and weights (pl, k, $\omega l, k, k=1,2)$ for each point, the output function

$\mathrm{Z}$ will be calculated for each variable and for each concentrated point $Z(l, k)$ based on $\mathrm{F}\left(\mathrm{M}_{\mathrm{p} 1}, \mathrm{M}_{\mathrm{p} 2}, \ldots, \mathrm{p}_{\mathrm{lk}}, \ldots, \mathrm{M}_{\mathrm{pm}}\right)$, which is computed according to:

$$
E\left(Z^{J}\right) \cong \sum_{l=1}^{m} \sum_{k=1}^{k} w_{l k} \times\left[F\left(M_{p 1}, M_{p 2}, \ldots, p_{l k}, \ldots, M_{p m}\right)\right]^{j}
$$

\section{Proposed Method}

The proposed optimization technique in this study is based on (WCA). The (WCA) simulates the flow of rivers and streams toward the sea and derives from monitoring the water cycle process [41]. The complete details of the multi-objective water cycle algorithm (MOWCA) are tracked step by step as follows [42]:

Step 1: The initial parameter of the WCA: Npop, Nsr, dmax, and Maximum_Iteration are chosen.

Step 2: a random initial population and the initial streams, rivers, and sea are generated by using equations as below.

$$
\begin{gathered}
\text { Total population }=\left[\begin{array}{c}
\text { Sea River } 1, \text { Sea River 2, Sea River } 3 \\
\text { Stream } N_{s r}+1, \text { Stream } N_{s r}+2, \text { Stream } N_{s r}+3 \\
\text { Stream } N_{p o p}
\end{array}\right] \\
\mathrm{N}_{\mathrm{sr}}=\text { Number of Rivers }+1 \\
\mathrm{~N}_{\text {Stream }}=\mathrm{N}_{\mathrm{pop}}-\mathrm{N}_{\mathrm{sr}}
\end{gathered}
$$

Step 3: The value of multi-objective functions for each stream are calculated by:

$$
C_{i}=\text { Cost }_{i}=f\left(x_{1}^{i}, x_{2}^{i}, \ldots, x_{3}^{i}\right)
$$

Step 4: Calculate the intensity of flow for river and sea by:

$$
N s_{n}=\text { round }\left\{\left|\frac{\operatorname{cost}_{n}}{\sum_{i=1}^{N_{s r} \operatorname{cost}_{i}}}\right| \times N_{\text {Stream }}\right\}, n=1,2, \ldots, N_{s r}
$$

Step 5: Calculate the flow of streams into the rivers by:

$$
\vec{X}_{\text {stream }}^{i+1}=\vec{X}_{\text {stream }}^{i+1}+\operatorname{rand} \times c \times\left(\vec{X}_{\text {River }}^{i}-\vec{X}_{\text {stream }}^{i+1}\right)
$$

Step 6: Calculate the flow of rivers into the sea by:

$$
\overrightarrow{\mathrm{X}}_{\text {stream }}^{\mathrm{i}+1}=\overrightarrow{\mathrm{X}}_{\text {stream }}^{\mathrm{i}+1}+\operatorname{rand} \times \mathrm{c} \times\left(\overrightarrow{\mathrm{X}}_{\text {Sea }}^{\mathrm{i}+1}-\overrightarrow{\mathrm{X}}_{\text {stream }}^{\mathrm{i}+1}\right)
$$

Step 7: Replace the positions of river and stream which achieves the best solution.

Step 8: Replace the position of river with the sea which achieves the best solution.

Step 9: The evaporation condition which can be obtained from the pseudo code are review.

Step 10: The precipitation process will be started after the evaporation condition is attained as follows: 


$$
\vec{X}_{\text {stream }}^{\text {new }}=\overrightarrow{L B}+\operatorname{rand} \times(\overrightarrow{U B}-\overrightarrow{L B})
$$

Step 11: Reduce the dmax using:

$$
\mathrm{d}_{\max }^{\mathrm{i}+1}=\mathrm{d}_{\max }^{\mathrm{i}}-\frac{\mathrm{d}_{\text {max }}^{\mathrm{i}}}{\text { maxIteration }}
$$

Step 12: If the termination criteria are satisfied, the algorithm will be ended. Otherwise, return back to step 5 .

Pseudo-codes of the MOWCA algorithm is provided in Algorithm 1 [35]. The flowchart of the water cycle optimization algorithm is shown in Figure 1 [36].

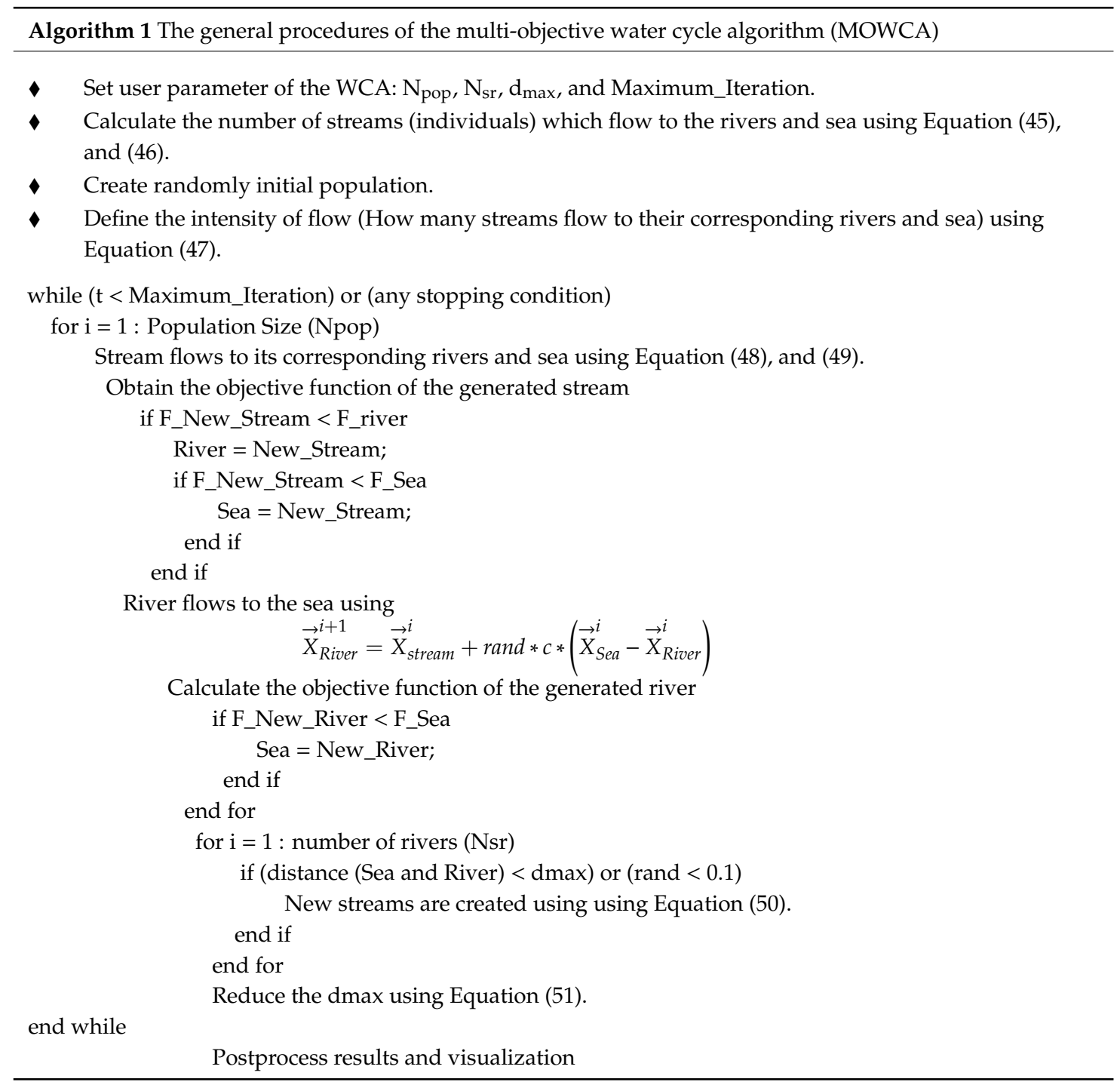




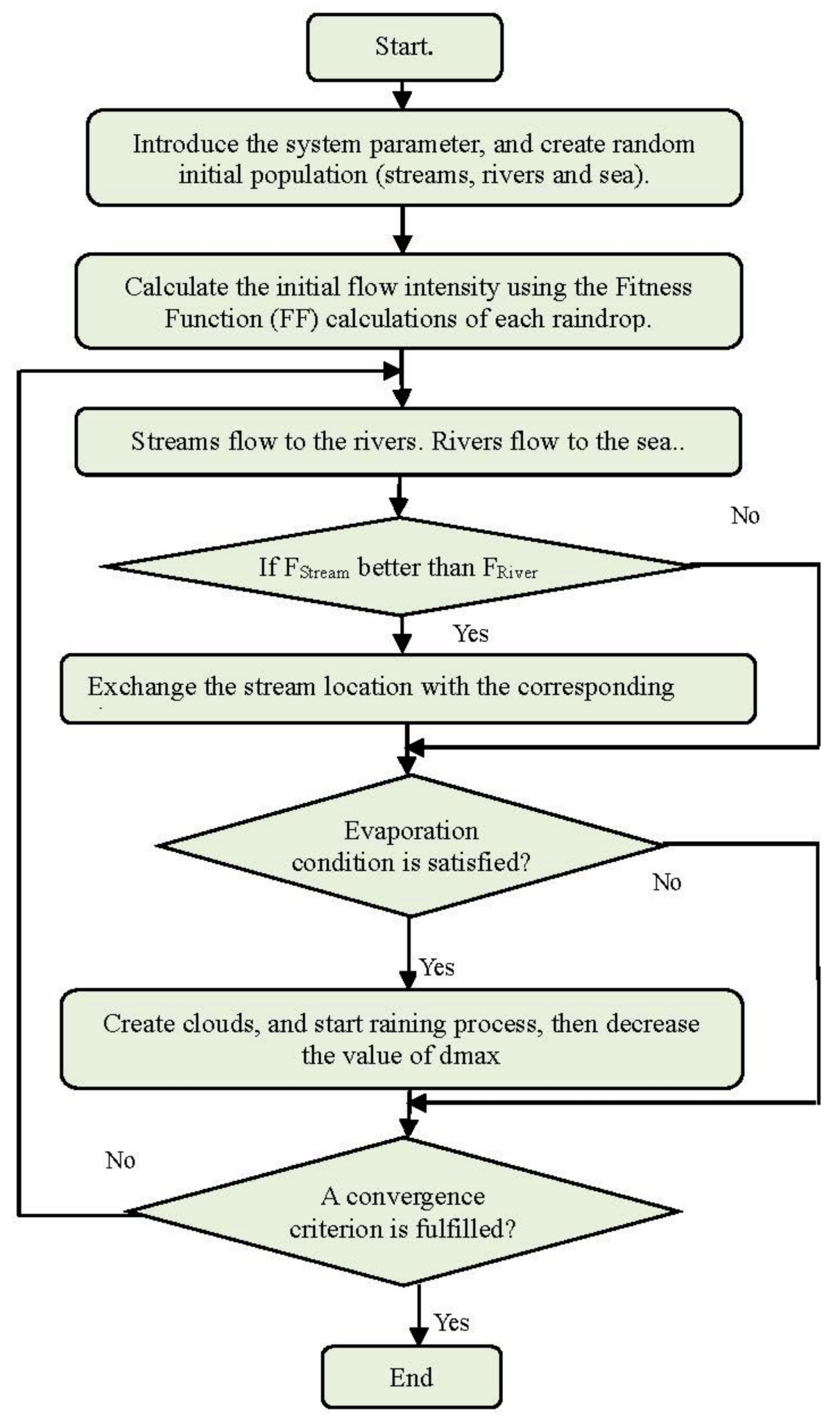

Figure 1. Flowchart of multi-objective water cycle algorithm (MOWCA).

\section{Simulation Results Based on MOWCA}

This part indicates the impact of the proposed method (MOWCA method) considering decreasing the power losses, voltage deviation, cost, and pollutant gas emission of the RDS. The suggested algorithm has been utilized on big RDS. An analytical software tool has been developed in MATLAB 
to run load flow, based Newoton-Raphson method and determine optimal location and size of DES. The study scenarios are tabulated in Table 5.

Table 5. The suggested different scenario studied in this article.

\begin{tabular}{|c|c|c|c|c|}
\hline Scenario \# & Case \# & Load Model & Season & System \\
\hline Scenario 1 & Case 1 & Constant & & \multirow{7}{*}{ IEEE 118} \\
\hline Scenario 2 & Case 2 & Agricultural & Summer \& Winter & \\
\hline Scenario 3 & Case 3 & Industrial & & \\
\hline \multirow{2}{*}{ Scenario 4} & Case 4 & \multirow{2}{*}{ Residential } & Summer & \\
\hline & Case 5 & & Winter & \\
\hline \multirow{2}{*}{ Scenario 5} & Case 6 & \multirow{2}{*}{ Commercial } & Summer & \\
\hline & Case 7 & & Winter & \\
\hline
\end{tabular}

\section{IEEE 118 bus radial distribution system}

The IEEE 118-bus (RDS) is large scale study system includes 117 buses and 118 branches with a total reactive and real load powers of $17041.07 \mathrm{kVAr}$ and 22,709.72 $\mathrm{kW}$, respectively, as shown in Figure 2 [43]. The MVA and kV base of the test system are100 MVA and $11 \mathrm{kV}$, respectively. The total reactive and real power losses are $978.7 \mathrm{kVAr}$ and $1298.1 \mathrm{~kW}$, respectively. System data is taken from [44]. Regarding the uncertainty in the load demand, the normal distribution function is performed and injected at loads on buses 21, 76, and 110. The total numbers of MT, FC, PV, WT units are 4, 4, 2, and 2 units, respectively. MT, FC, PV, WT unit sizes are $150 \mathrm{~kW}, 400 \mathrm{~kW}, 300 \mathrm{~kW}$, and $15 \mathrm{~kW}$, respectively.

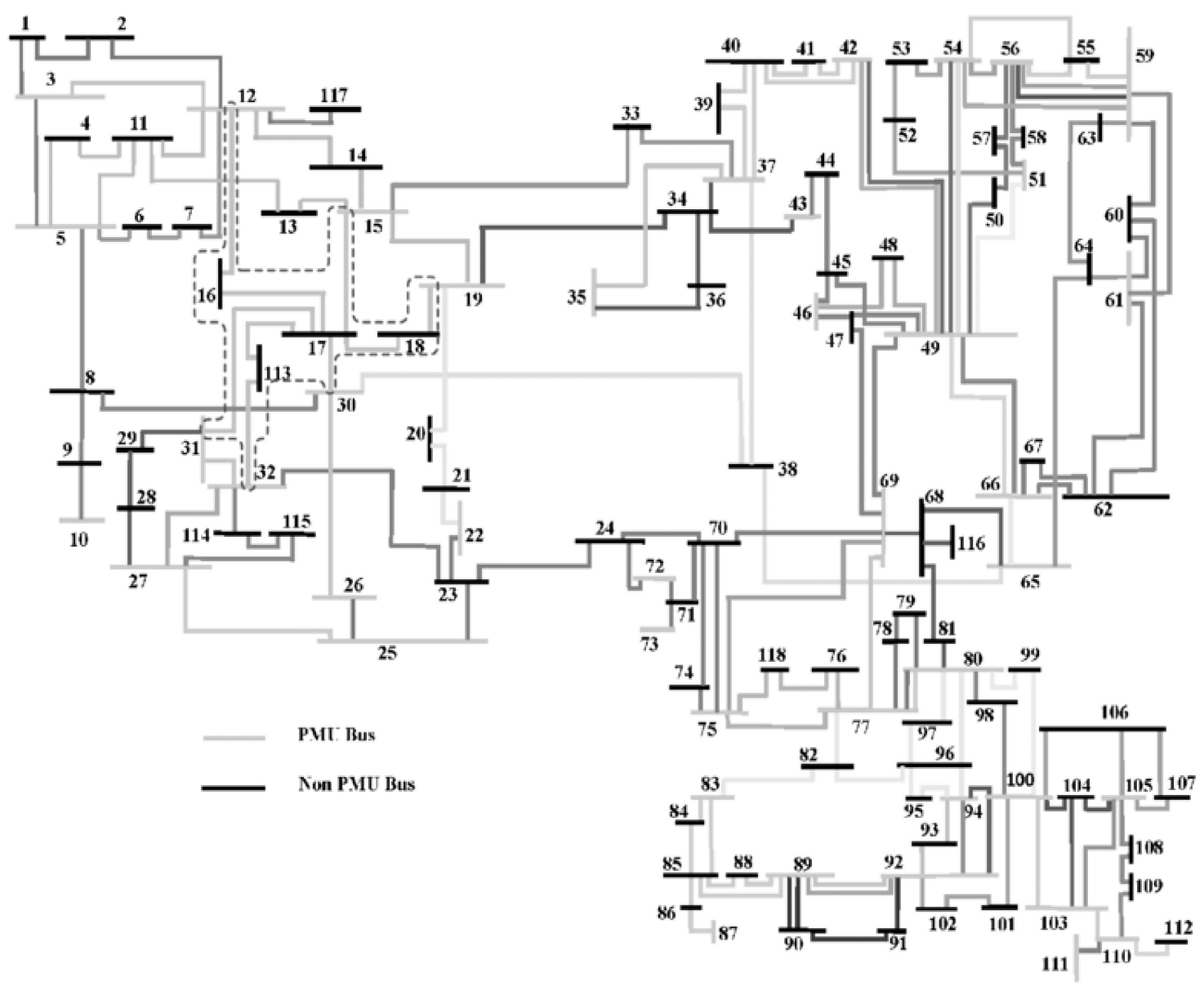

Figure 2. The IEEE 118 bus system diagram [44]. 


\section{Scenario 1 (constant load model)}

In this case the performance of system is analyzed under three different values of the standard deviation considering constant load model based on MOWCA. The Pareto fronts and the best compromise solution are shown in Figure 3a-c, it's clear that the Pareto solutions at SD $=0.1$ of the considered load level are the best solution for improving all objective functions. The three objectives under the effect of SD are illustrated in Figure 3d, It is observed that the $10 \%$ of the considered load level is succeeded in minimizing power loss, voltage deviation, and the emission of the network effectively, but the min cost value obtained when SD equal to 0.05 or 0.01 of the considered load level is closed to the value obtained when $\mathrm{SD}=0.1$ of the considered load level. The optimal allocations of mixed DERs are listed in Table 6. The optimization results achieved by proposed the MOWCA is given in Table 7 , it's clear that the power loss reduced by $15.14 \%$.

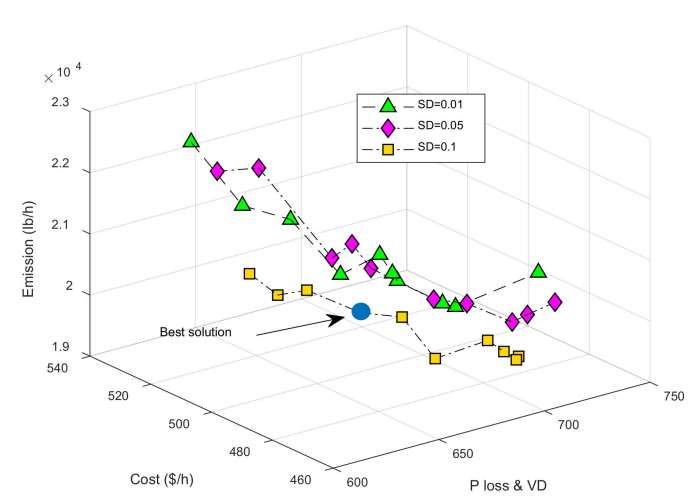

(a)

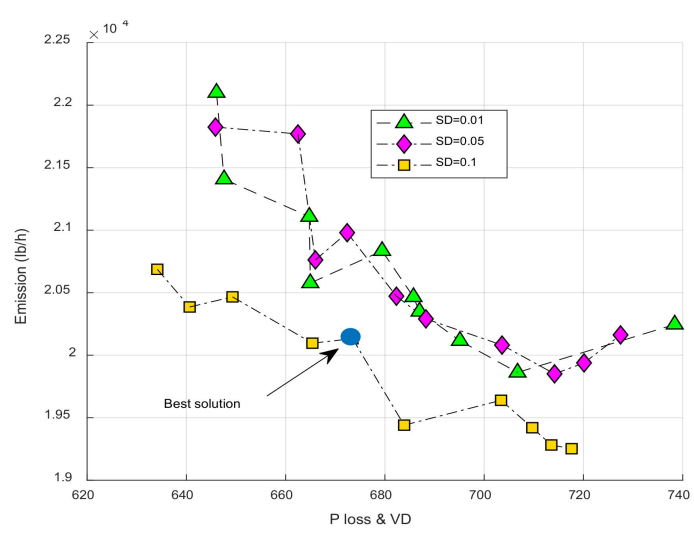

(c)

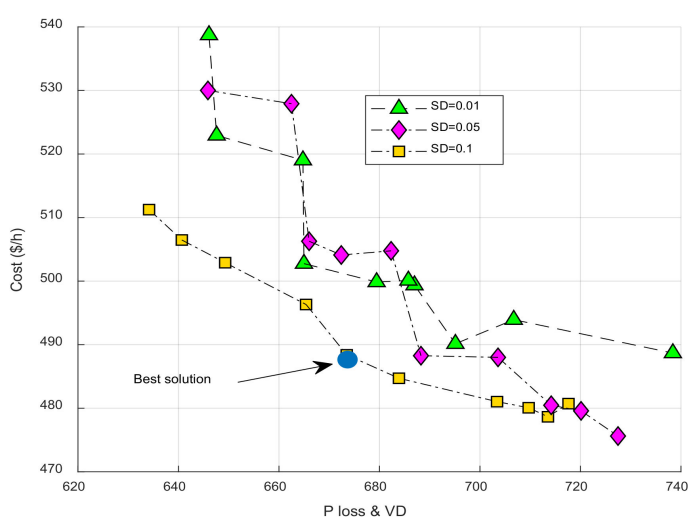

(b)

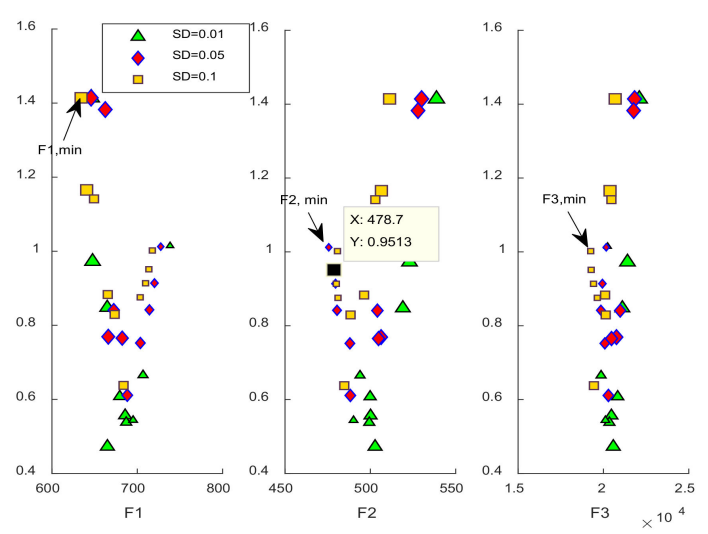

(d)

Figure 3. The performance of network under constant load model (scenario 1), best solution obtained at $\mathrm{SD}=0.1$ are cleared in $(\mathbf{a}-\mathbf{c})$, min value of different objectives is shown in Figure (d).

Table 6. Optimal allocation of different DERs for Scenario 1.

\begin{tabular}{ccccccc}
\hline Scenario\# & Case \# & SD Value & $\begin{array}{c}\text { MT Size MW, } \\
\text { (Location (Bus No)) }\end{array}$ & $\begin{array}{c}\text { FC Size MW, } \\
\text { (Location (Bus No)) }\end{array}$ & $\begin{array}{c}\text { PV Size MW, } \\
\text { (Location (Bus No)) }\end{array}$ & $\begin{array}{c}\text { WT Size MW, } \\
\text { (Location (Bus No)) }\end{array}$ \\
\hline \multirow{2}{*}{1} & \multirow{2}{*}{0.1} & $0.082006(44)$ & $0(118)$ & & \\
& & $0.15(32)$ & $0.4(77)$ & $0.13295(72)$ & $0.060799(117)$ \\
& & $0.03612(118)$ & $0.4(18)$ & $0.16116(51)$ & $0.052414(34)$ \\
\hline \multicolumn{2}{l}{ Cost for Scenario 1 $(\$ / \mathrm{h})$} & 11.5622 & 64.8803 & 9.1897 & 3.15 \\
\hline
\end{tabular}


Table 7. Optimization results obtained for Constant load model.

\begin{tabular}{cccccccccc}
\hline Scenario \# & Case \# & SD Value & $\boldsymbol{P}_{\text {loss }} \mathbf{k W}$ & $\boldsymbol{Q}_{\text {loss }} \mathbf{k V A}$ & $\boldsymbol{V D}(\mathbf{P U})$ & $\boldsymbol{V}_{\min }\left(\right.$ Location) $\mathbf{F}_{\mathbf{1}}$ & $\begin{array}{c}\mathbf{F}_{2} \\
(\mathbf{\$} / \mathbf{h})\end{array}$ & $\begin{array}{c}\mathbf{F}_{3} \\
(\mathrm{Ib} / \mathbf{h})\end{array}$ \\
\hline 1 & 1 & 0.1 & 1101.5774 & 833.1786 & 4.8027 & $0.892(74)$ & 662.87 & 507.774 & $20,981.38$ \\
\hline
\end{tabular}

\section{Scenario 2 (Agricultural load model)}

In this scenario, the agricultural load model is presented under a different standard deviation values, the value of $\alpha$ and $\beta$ in the winter season is the same value in the summer season, there is one optimization result for two seasons. Pareto frontiers and their 2D projections are plotted in Figure $4 \mathrm{a}-\mathrm{c}$. It is evident that the significant reduction in all objective functions achieved by MOWCA algorithm considering SD $=5 \%$ of the considered load level. Figure $4 \mathrm{~d}$ shows the effect of SD value on the different objective function. The size and location of different DERs and the optimization results for improving system performance at $\mathrm{SD}=0.05$ are illustrated in Tables 8 and 9, respectively, it is cleared from optimization results that the total sizes of new electric sources under using agricultural load model are higher that the sizes obtained under using constant load model. The power loss is decreased from $1012.6 \mathrm{~kW}$ to $901.8219 \mathrm{~kW}$, the voltage deviation is reduced to $4.3731 \mathrm{PU}$. The total emission is reduced from $20,609 \mathrm{Ib} / \mathrm{h}$ to $18,936.083 \mathrm{Ib} / \mathrm{h}$.

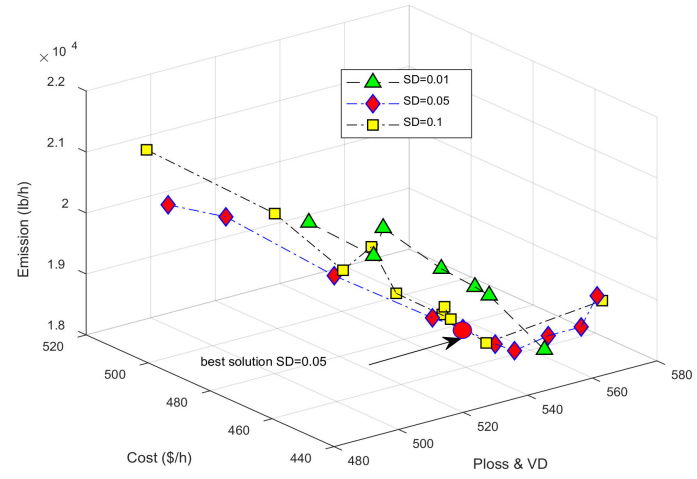

(a)

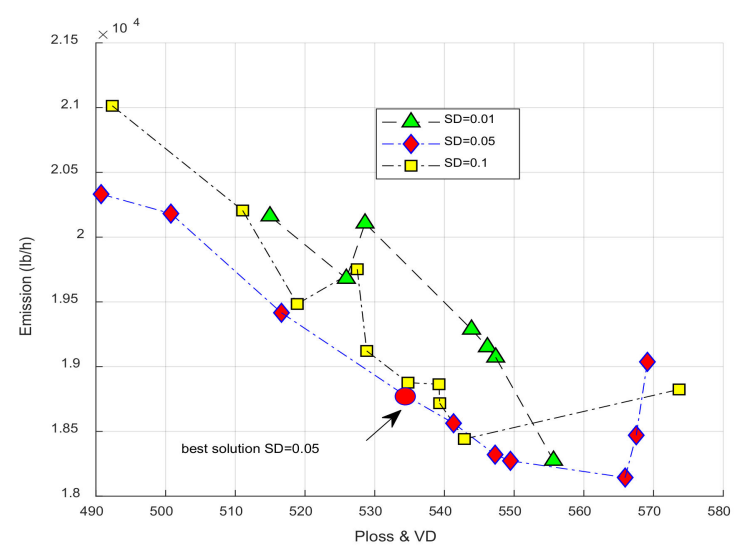

(c)

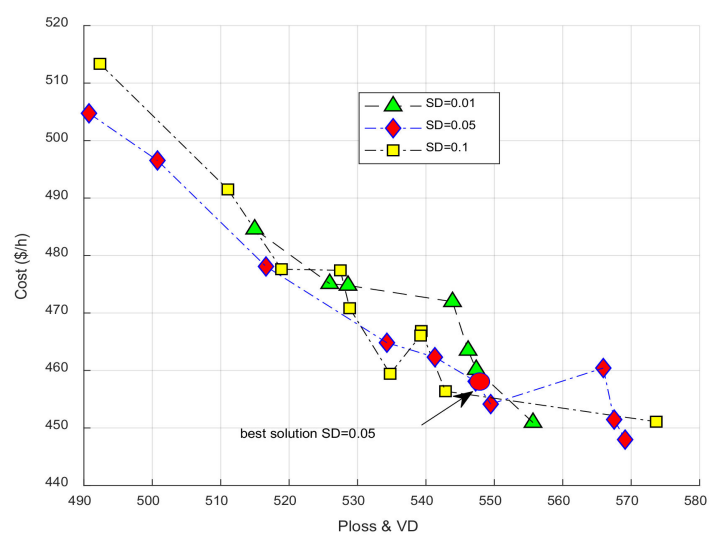

(b)

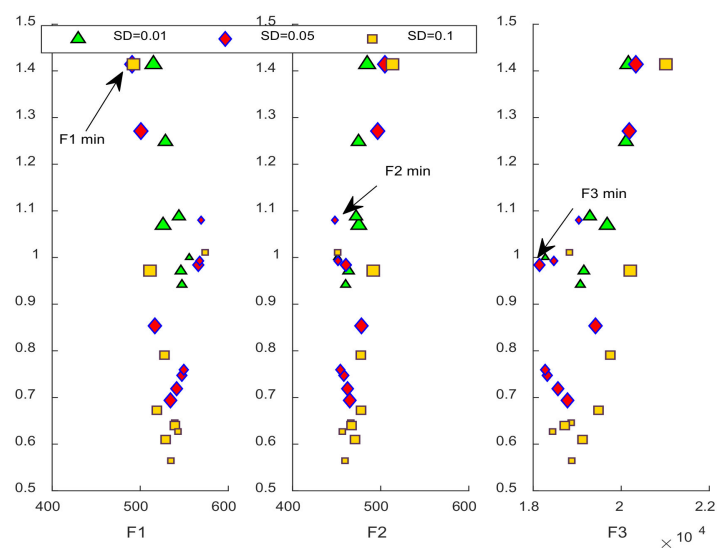

(d)

Figure 4. The performance of network under agricultural load model, best solution obtained by $\mathrm{SD}=0.05$ of the considered load level is cleared in $(\mathbf{a}-\mathbf{c})$, min value of different objectives is plotted in Figure (d). 
Table 8. Optimal allocation of different DERs for Scenario 2.

\begin{tabular}{|c|c|c|c|c|c|c|}
\hline Scenario\# & Case \# & SD Value & $\begin{array}{c}\text { MT Size MW, } \\
\text { (Location (Bus No)) }\end{array}$ & $\begin{array}{c}\text { FC Size MW, } \\
\text { (Location (Bus No)) }\end{array}$ & $\begin{array}{c}\text { PV Size MW, } \\
\text { (Location (Bus No)) }\end{array}$ & $\begin{array}{c}\text { WT Size MW, } \\
\text { (Location (Bus No)) }\end{array}$ \\
\hline 2 & 2 & 0.05 & $\begin{array}{c}0.12405(61) \\
0.08396(32) \\
0.053504(75) \\
0.10243(26)\end{array}$ & $\begin{array}{c}0.35906(52) \\
0.13309(118) \\
0.29997(36) \\
0.25944(33)\end{array}$ & $\begin{array}{c}0.1509(90) \\
0.16562(14)\end{array}$ & $\begin{array}{c}0.048503(6) \\
0.057713(47)\end{array}$ \\
\hline Cost $\mathrm{f}$ & Scenari & $2(\$ / \mathrm{h})$ & 15.2993 & 68.4034 & 9.3018 & 3.115 \\
\hline
\end{tabular}

Table 9. Optimization results obtained for Agricultural load model.

\begin{tabular}{|c|c|c|c|c|c|c|c|c|}
\hline Scenario\# & Case \# & SD Value & $P_{\text {loss }} \mathrm{kW}$ & $Q_{\text {loss }} \mathrm{kVA}$ & $V D(P U)$ & $V_{\min }$ (Location) $\mathrm{F}_{1}$ & $\begin{array}{c}F_{2} \\
(\$ / h)\end{array}$ & $\begin{array}{c}\mathrm{F}_{3} \\
(\mathrm{Ib} / \mathrm{h})\end{array}$ \\
\hline 2 & 2 & 0.05 & 901.8219 & 677.6467 & 4.3731 & $0.8961(77)$ & 466.1954 & $18,936.083$ \\
\hline
\end{tabular}

\section{Scenario 3 (Industrial load model)}

This scenario displays the industrial load as a load model, the Pareto solutions for proposed algorithm under three values of SD are illustrated in Figure 5a-c. Figure $5 \mathrm{~d}$ indicates the effect of three values of SD on three objectives. Obviously, using $\mathrm{SD}=1 \%$ of the considered load level provides highly accurate results compared to results obtained with other values of SD for reducing the power loss, voltage deviation. In addition, the results obtained at $\mathrm{SD}=5 \%$ of the considered load level closed to the results obtained at $\mathrm{SD}=1 \%$. SD $=0.05$ of the considered load level is the best value for minimizing cost, in addition, the sizes of DERs are reduced and power loss is increased compared to the results at $\mathrm{SD}=0.01$ or 0.1 . The performance of network at $\mathrm{SD}=0.01$, and 0.05 are found in Tables 10 and 11 . From the optimization result, $\mathrm{min}$ active and reactive loss and min voltage deviation obtained with $\mathrm{SD}=0.01$ but min cost and emission obtained from $\mathrm{SD}=0.05$. The power loss is reduced from $1235 \mathrm{~kW}$ to $901.8219 \mathrm{~kW}$, the voltage deviation is decreased to $4.1282 \mathrm{PU}$. The total emissions are reduced from $21,750 \mathrm{Ib} / \mathrm{h}$ to $19,073.5745 \mathrm{Ib} / \mathrm{h}$.

Table 10. Optimal allocation of different DERs for Scenario 3.

\begin{tabular}{|c|c|c|c|c|c|c|}
\hline Scenario\# & Case \# & SD Value & $\begin{array}{c}\text { MT Size MW, } \\
\text { (Location (Bus No)) }\end{array}$ & $\begin{array}{c}\text { FC Size MW, } \\
\text { (Location (Bus No)) }\end{array}$ & $\begin{array}{c}\text { PV Size MW, } \\
\text { (Location (Bus No)) }\end{array}$ & $\begin{array}{c}\text { WT Size MW, } \\
\text { (Location (Bus No)) }\end{array}$ \\
\hline \multirow{9}{*}{3} & \multirow{9}{*}{3} & \multirow{3}{*}{0.01} & $0.082006(44)$ & $0(118)$ & & \\
\hline & & & $0(90)$ & $0.4(18)$ & $0.16116(51)$ & $0.052414(34)$ \\
\hline & & & $0.036116(118)$ & $0.17966(49)$ & & \\
\hline & & $\begin{array}{l}\text { Cost } \\
(\$ / h)\end{array}$ & 11.5622 & 64.8803 & 9.1897 & 3.15 \\
\hline & & \multirow{4}{*}{0.05} & $0.11703(17)$ & $0.26878(53)$ & \multirow{4}{*}{$\begin{array}{l}0.15813(50) \\
0.15277(74)\end{array}$} & \multirow{4}{*}{$\begin{array}{l}0.055867(31) \\
0.061031(89)\end{array}$} \\
\hline & & & $0.13584(72)$ & $0.30641(34)$ & & \\
\hline & & & $0.15(50)$ & $0.31301(51)$ & & \\
\hline & & & $0.059788(2)$ & $0.17517(17)$ & & \\
\hline & & $\begin{array}{l}\text { Cost } \\
(\$ / h)\end{array}$ & 19.1494 & 60.3987 & 8.483 & 3.1684 \\
\hline
\end{tabular}

Table 11. Optimization results obtained for industrial load model.

\begin{tabular}{cccccccccc}
\hline Scenario\# & Case \# & SD Value & $\boldsymbol{P}_{\text {loss }} \mathbf{k W}$ & $\boldsymbol{Q}_{\text {loss }} \mathbf{k V A}$ & $\boldsymbol{V D}$ (PU) & $\boldsymbol{V}_{\text {min }}$ (Location) $\mathbf{F}_{\mathbf{1}}$ & $\begin{array}{c}\mathbf{F}_{\mathbf{2}} \\
\mathbf{( \$ / \mathbf { h } )}\end{array}$ & $\begin{array}{c}\mathbf{F}_{\mathbf{3}} \\
(\mathbf{I b} / \mathbf{h})\end{array}$ \\
\hline \multirow{2}{*}{3} & \multirow{2}{*}{3} & 0.01 & 1043.894 & 791.5462 & 4.6901 & $0.8958(74)$ & 628.2126 & 505.3910 & 20870.6326 \\
\cline { 3 - 9 } & & 0.05 & 1054.159 & 782.4240 & 4.7222 & $0.8832(77)$ & 634.3846 & 494.5313 & 20465.8126 \\
\hline
\end{tabular}




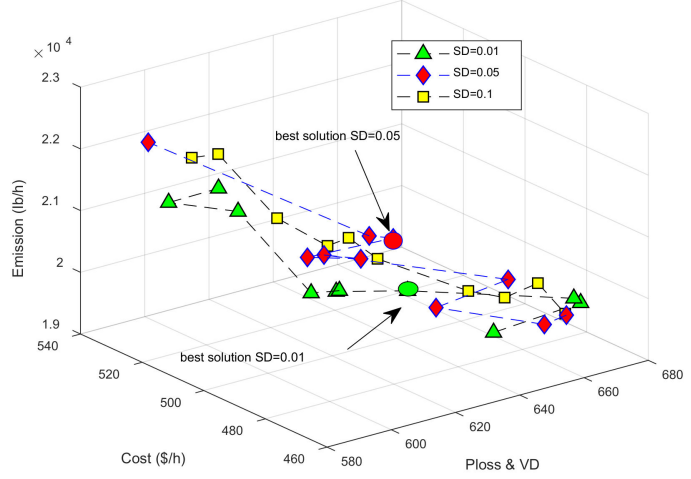

(a)

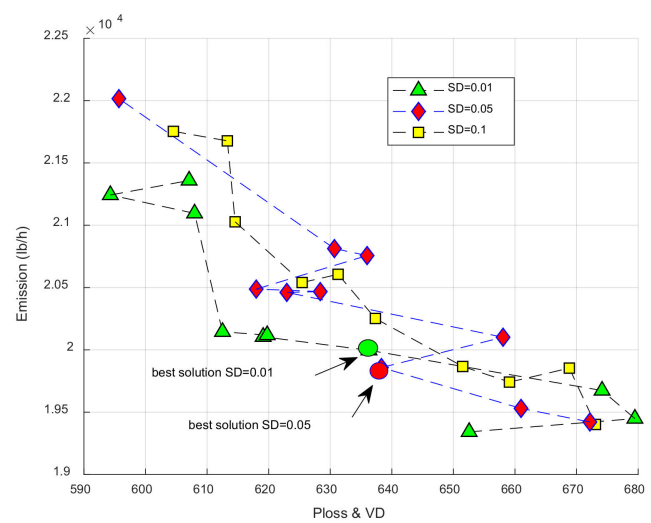

(c)

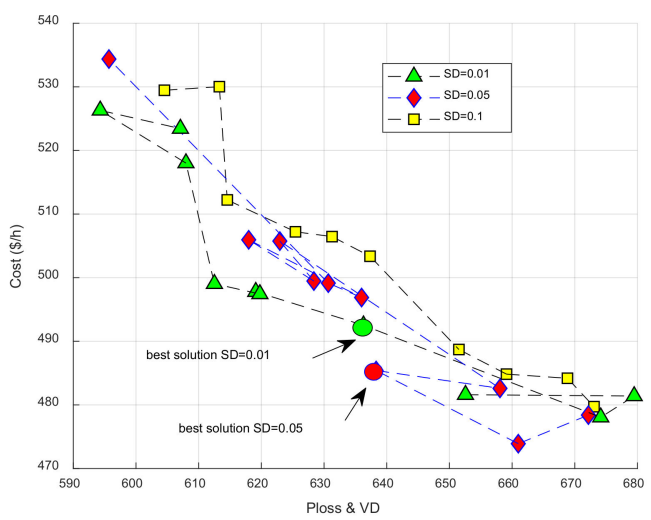

(b)

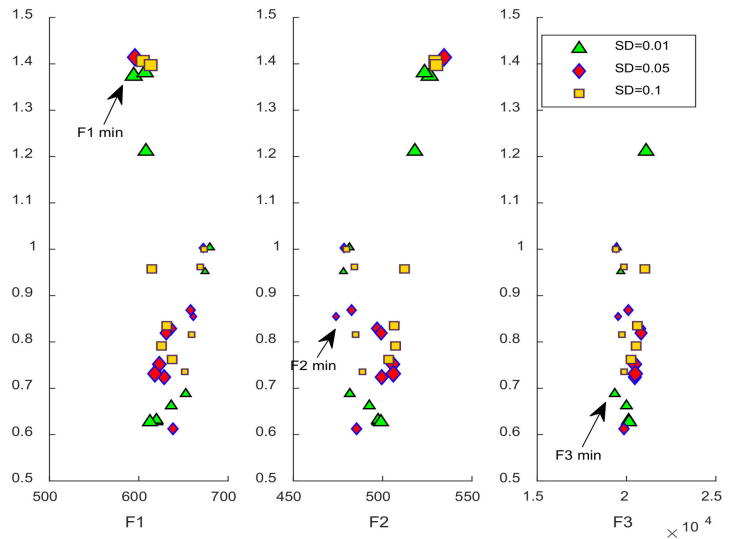

(d)

Figure 5. The performance of network under Industrial load model, best solution obtained by SD $=0.01$ and $\mathrm{SD}=0.05$ are cleared in $(\mathbf{a}-\mathbf{c})$, min value of different objectives is shown in Figure (d).

\section{Scenario 4 (Residential load model)}

MOWCA algorithms is employed to determine the best size and placement of DERs based on deterministic planning under residential load model and select best value of SD in winter and summer seasons. The optimization results obtained from the optimization algorithm under Residential load model in two seasons are tabulated in Tables 12 and 13.

Table 12. Optimal allocation of different DERs for Scenario 4.

\begin{tabular}{|c|c|c|c|c|c|c|}
\hline Scenario\# & Case \# & SD Value & $\begin{array}{c}\text { MT Size MW, } \\
\text { (Location (Bus No)) }\end{array}$ & $\begin{array}{c}\text { FC Size MW, } \\
\text { (Location (Bus No)) }\end{array}$ & $\begin{array}{c}\text { PV Size MW, } \\
\text { (Location (Bus No)) }\end{array}$ & $\begin{array}{c}\text { WT Size MW, } \\
\text { (Location (Bus No)) }\end{array}$ \\
\hline \multirow{4}{*}{4} & 4 & $\begin{array}{c}0.05 \\
\text { (winter } \\
\text { season) }\end{array}$ & $\begin{array}{c}0.13146(74) \\
0.11598(22) \\
0.090361(2) \\
0.039559(16)\end{array}$ & $\begin{array}{c}0.22102(2) \\
0.22165(32) \\
0.19975(62) \\
0.39385(54)\end{array}$ & $\begin{array}{l}0.15144(75) \\
0.15817(34)\end{array}$ & $\begin{array}{l}0.046366(66) \\
0.057362(60)\end{array}$ \\
\hline & \multirow{3}{*}{5} & $\begin{array}{l}\text { Cost } \\
(\$ / \mathrm{h})\end{array}$ & 15.8226 & 56.824 & 9.2672 & 3.1025 \\
\hline & & $\begin{array}{c}0.1 \\
\text { (summer } \\
\text { season) }\end{array}$ & $\begin{array}{c}0.098701(112) \\
0.077297(22) \\
0.028257(118) \\
0.15(73)\end{array}$ & $\begin{array}{c}0.27066(33) \\
0.06927(59) \\
0.4(50) \\
0.36177(42)\end{array}$ & $\begin{array}{l}0.13787(24) \\
0.15092(97)\end{array}$ & $\begin{array}{c}0.060744(2) \\
0.066703(118)\end{array}$ \\
\hline & & $\begin{array}{l}\text { Cost } \\
(\$ / h)\end{array}$ & 14.9214 & 70.8601 & 9.1631 & 2.8876 \\
\hline
\end{tabular}


Table 13. Optimization results obtained for Residential load model.

\begin{tabular}{cccccccccc}
\hline Scenario\# Case\# & SD Value & $\boldsymbol{P}_{\text {loss }} \mathbf{k W}$ & $Q_{\text {loss }} \mathbf{k V A}$ & $V D(\mathrm{PU})$ & $V_{\min }$ (Location) $\mathbf{F}_{\mathbf{1}}$ & $\begin{array}{c}\mathbf{F}_{2} \\
\mathbf{( \$ / \mathbf { h } )}\end{array}$ & $\begin{array}{c}\mathbf{F}_{3} \\
(\mathbf{I b} / \mathbf{h})\end{array}$ \\
\hline \multirow{2}{*}{4} & 4 & $\begin{array}{c}0.05 \\
\text { (winter season) }\end{array}$ & 792.7669 & 604.0108 & 4.1282 & $0.9111(77)$ & 477.3114 & 463.0627 & 19073.5745 \\
\cline { 2 - 8 } & 5 & $\begin{array}{c}0.1 \\
\text { (summer season) }\end{array}$ & 836.7660 & 636.9934 & 4.2342 & $0.9002(77)$ & 503.7533 & 480.5165 & 19561.3486 \\
\hline
\end{tabular}

\section{Case 4 (at winter season)}

The Pareto solutions for proposed algorithm and their 2-D projections are visualized in Figure 6a-c and three objective functions are shown in Figure $6 \mathrm{~d}$; it is obvious that the SD $=0.1$ is the suitable value for minimizing loss and voltage deviation considering residential load model in winter season. For minimizing cost and Emission, the SD value must be reduced to equal to 0.05 . The power loss is reduced by $14.258 \%$, the voltage deviation is reduced to $4.1282 \mathrm{PU}$. The total emissions are reduced from $20,483 \mathrm{Ib} / \mathrm{h}$ to $19,073.5745 \mathrm{Ib} / \mathrm{h}$.

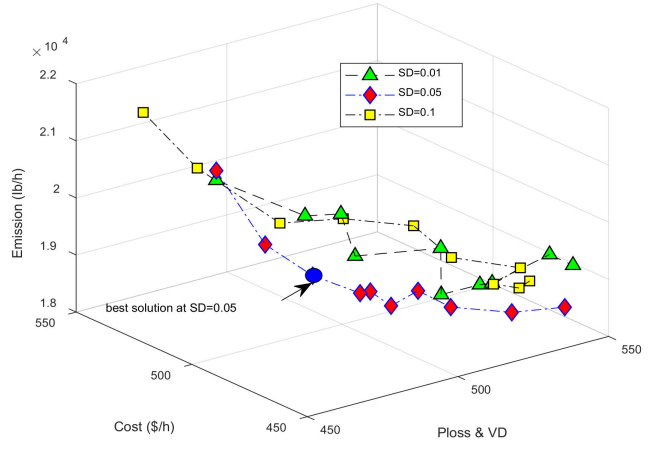

(a)

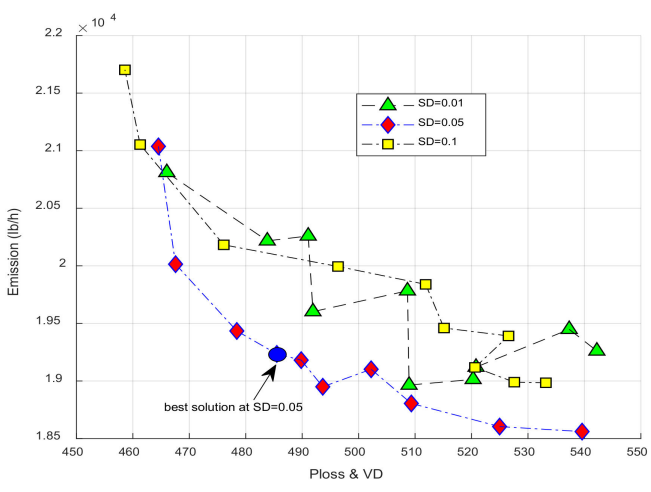

(c)

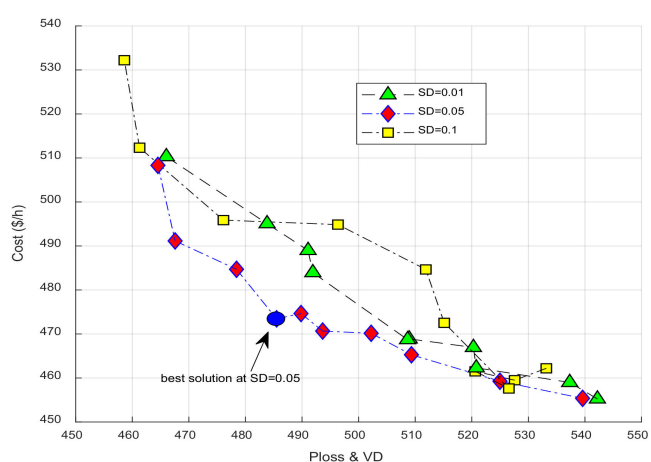

(b)

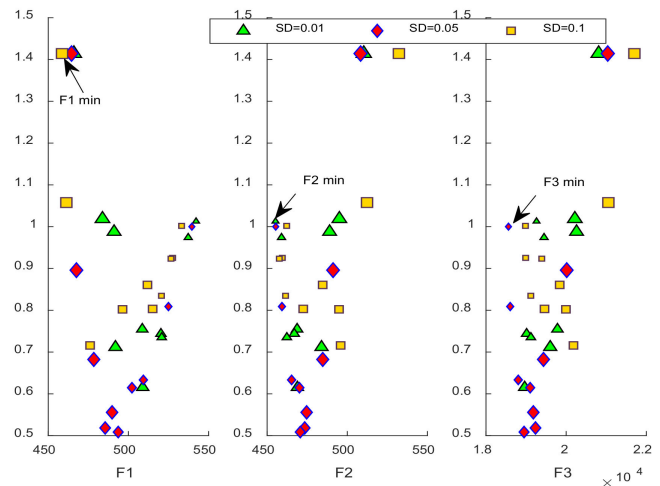

(d)

Figure 6. The performance of network under Residential load model in the winter season, best solution obtained by $\mathrm{SD}=0.05$ is shown in Figure $(\mathbf{a}-\mathbf{c})$, min value of different objectives is shown in Figure (d).

\section{Case 5 (at summer season)}

In this case, the optimal optimization results obtained under $\mathrm{SD}=0.1$ with a residential load model in summer season, Pareto frontiers and their 2D projections are shown in Figure 7a-c, the effect of SD values on the different objective functions are cleared in Figure $7 \mathrm{~d}$. The best performance of the system has been done in $\mathrm{SD}=0.1$, the power loss is decreased from $988.4 \mathrm{~kW}$ to $836.766 \mathrm{~kW}$, the voltage deviation is decreased to $4.2342 \mathrm{PU}$. The total emissions are reduced from $20,978 \mathrm{Ib} / \mathrm{h}$ to $19,561.3486 \mathrm{Ib} / \mathrm{h}$. 


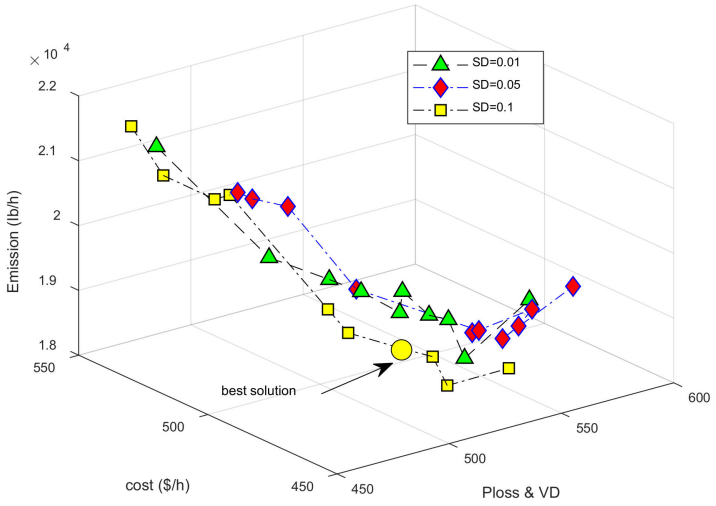

(a)

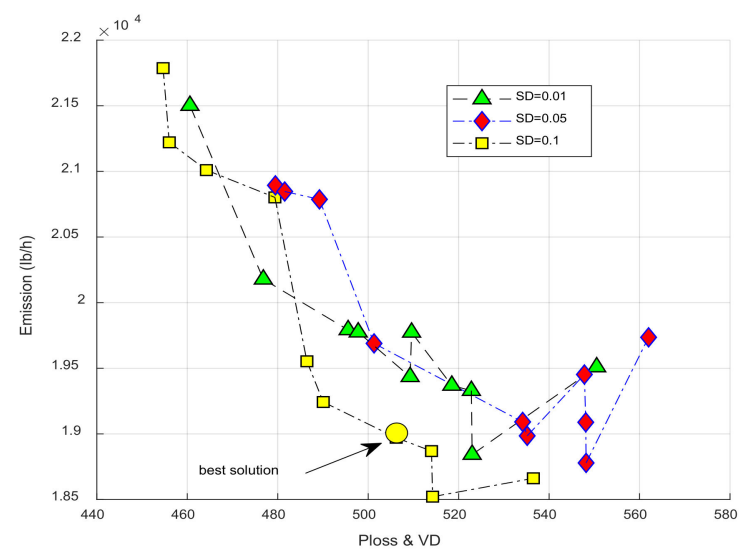

(c)

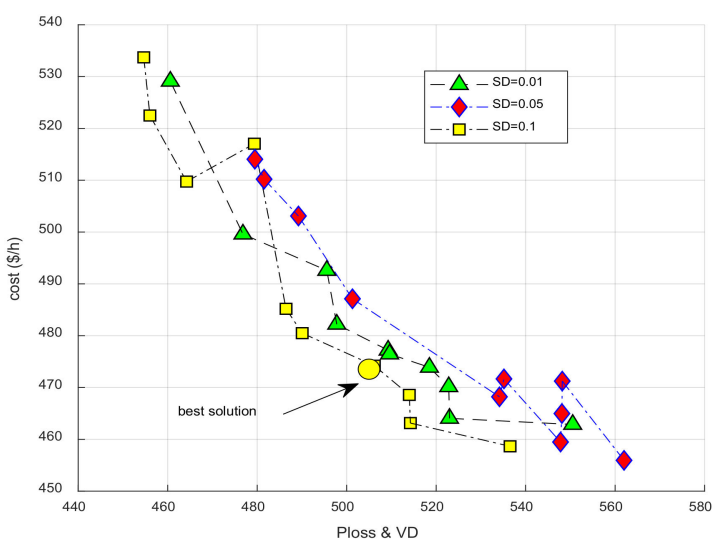

(b)

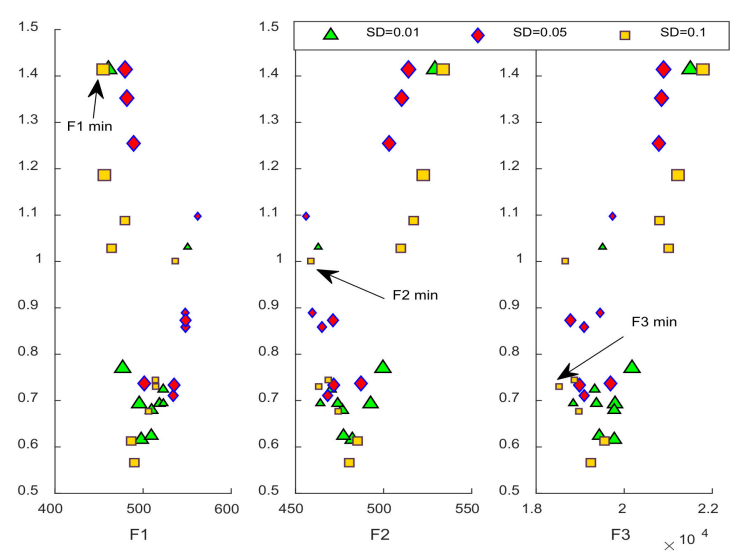

(d)

Figure 7. The performance of network under residential load model in the summer season, best solution obtained by $\mathrm{SD}=0.1$ is shown in Figure $(\mathbf{a}-\mathbf{c})$, a min value of different objectives is shown in Figure (d).

\section{Scenario 5 (Commercial load)}

This scenario consist of two cases depend on the seasons operation considering commercial load model. The obtained responses were deduced by utilizing the proposed MOWCA considering commercial load model are listed in Table 14. The optimal allocation of DERs is depicted in Table 15.

Table 14. Optimization results obtained for Commercial load model.

\begin{tabular}{cccccccccc}
\hline $\begin{array}{c}\text { Scenario } \\
\#\end{array}$ & $\begin{array}{c}\text { Case } \\
\#\end{array}$ & SD value & $\boldsymbol{P}_{\text {loss }} \mathbf{k W}$ & $Q_{\text {loss }} \mathbf{k V A}$ & $V D(\mathbf{P U})$ & $V_{\text {min }}$ (location) $\mathbf{F}_{\mathbf{1}}$ & $\begin{array}{c}\mathbf{F}_{2} \\
\mathbf{( \$ / \mathbf { h } )}\end{array}$ & $\begin{array}{c}\mathbf{F}_{3} \\
(\mathbf{I b} / \mathbf{h})\end{array}$ \\
\hline & 6 & $\begin{array}{c}0.05 \\
\text { (winter season) }\end{array}$ & 927.0367 & 698.3412 & 4.4545 & $\begin{array}{c}0.8919 \\
(77)\end{array}$ & 558.0038 & 467.0967 & 19430.2651 \\
\cline { 2 - 9 } & & $\begin{array}{c}0.1 \\
\text { (winter season) }\end{array}$ & 883.5892 & 672.4293 & 4.3833 & $\begin{array}{c}0.8977 \\
(77)\end{array}$ & 531.9068 & 474.6212 & 19899.8357 \\
\cline { 2 - 9 } & 7 & $\begin{array}{c}0.05 \\
\text { (summer season) }\end{array}$ & 871.2567 & 660.3310 & 4.3336 & $\begin{array}{c}0.9030 \\
(75)\end{array}$ & 524.4874 & 483.9017 & 20175.6564 \\
\hline & & $\begin{array}{c}0.1 \\
\text { (summer season) }\end{array}$ & 886.4362 & 671.0857 & 4.3348 & $\begin{array}{c}0.8957 \\
(77)\end{array}$ & 533.5956 & 489.5236 & 19704.4773 \\
\hline
\end{tabular}


Table 15. Optimal allocation of different DERs for Scenario 5.

\begin{tabular}{|c|c|c|c|c|c|c|}
\hline Scenario\# & Case \# & SD Value & $\begin{array}{c}\text { MT Size MW, } \\
\text { (Location (Bus No)) }\end{array}$ & $\begin{array}{c}\text { FC Size MW, } \\
\text { (Location (Bus No)) }\end{array}$ & $\begin{array}{c}\text { PV Size MW, } \\
\text { (Location (Bus No)) }\end{array}$ & $\begin{array}{c}\text { WT Size MW, } \\
\text { (Location (Bus No)) }\end{array}$ \\
\hline \multirow{7}{*}{5} & \multirow{4}{*}{6} & $\begin{array}{c}0.05 \\
\text { (winter } \\
\text { season) }\end{array}$ & $\begin{array}{c}0.015383(85) \\
0.15(42) \\
0(41) \\
0.095404(31)\end{array}$ & $\begin{array}{c}0.34248(54) \\
0.085885(50) \\
0(102) \\
0.26569(10)\end{array}$ & $\begin{array}{c}0.15077(53) \\
0.15509(117)\end{array}$ & $\begin{array}{l}0.061906(29) \\
0.056878(23)\end{array}$ \\
\hline & & $\begin{array}{l}\text { Cost } \\
(\$ / h)\end{array}$ & 11.2762 & 50.8856 & 9.2485 & 3.1778 \\
\hline & & $\begin{array}{c}0.1 \\
\text { (winter } \\
\text { season) }\end{array}$ & $\begin{array}{c}0.15(12) \\
0.11784(5) \\
0.15(73) \\
0(16)\end{array}$ & $\begin{array}{c}0(118) \\
0.16298(34) \\
0.39931(54) \\
0.22601(118)\end{array}$ & $\begin{array}{c}0.16696(113) \\
0.16203(51)\end{array}$ & $\begin{array}{c}0.05738(2) \\
0.057084(91)\end{array}$ \\
\hline & & $\begin{array}{l}\text { Cost } \\
(\$ / h)\end{array}$ & 17.4013 & 44.4291 & 9.3642 & 3.1562 \\
\hline & \multirow[t]{3}{*}{7} & $\begin{array}{l}\text { Cost } \\
(\$ / h)\end{array}$ & 14.6006 & 52.3329 & 9.2214 & 2.8777 \\
\hline & & $\begin{array}{c}0.1 \\
\text { (summer } \\
\text { season) }\end{array}$ & $\begin{array}{c}0.023133(42) \\
0.11116(74) \\
0.040849(57) \\
0.058025(113)\end{array}$ & $\begin{array}{c}0.38969(53) \\
0.4(54) \\
0.22774(59) \\
0.32221(118)\end{array}$ & $\begin{array}{l}0.13633(10) \\
0.16455(14)\end{array}$ & $\begin{array}{l}0.062158(105) \\
0.056239(19)\end{array}$ \\
\hline & & $\begin{array}{l}\text { Cost } \\
(\$ / h)\end{array}$ & 10.199 & 82.519 & 9.2236 & 3.1759 \\
\hline
\end{tabular}

\section{Case 6 (at winter season)}

The Pareto frontiers of proposed algorithm and the objective function analyzing under different standard deviation are depicted in Figure $8 \mathrm{a}-\mathrm{d}$, respectively. The results at SD $=5 \%$ are better compared to the results obtained at other values for minimizing loss and voltage deviation, however, the cost is reduced based on $\mathrm{SD}=10 \%$. The power loss is decreased by $15 \%$, the voltage deviation is reduced to 4.3833 PU. The total emission is decreased from $21,078 \mathrm{Ib} / \mathrm{h}$ to $19,704.4773 \mathrm{Ib} / \mathrm{h}$ at $\mathrm{SD}=0.05$. 


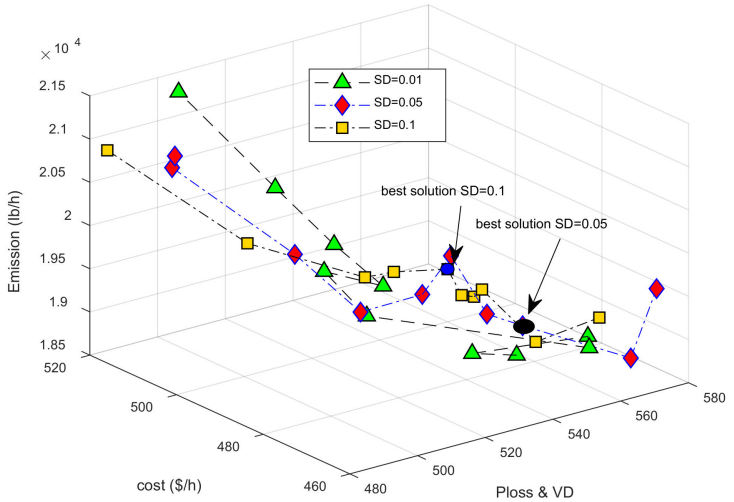

(a)

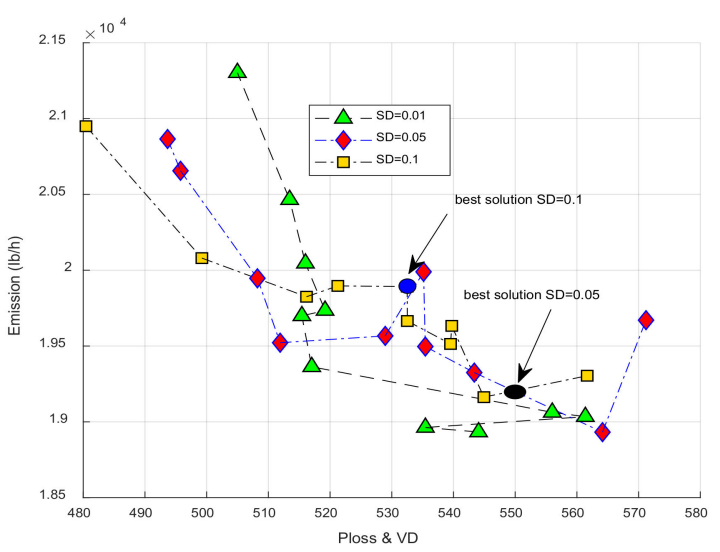

(c)

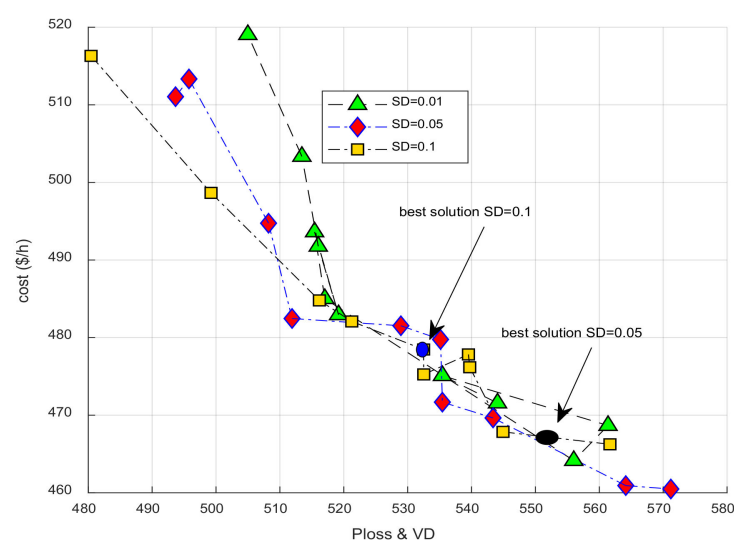

(b)
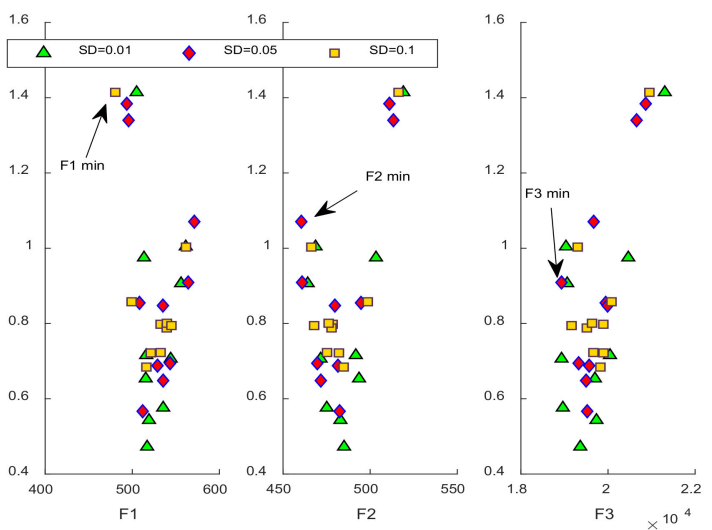

(d)

Figure 8. The performance of network under commercial load model in the winter season, best solution obtained at $\mathrm{SD}=0.1$ and $\mathrm{SD}=0.05$ are depicted in Figure $(\mathbf{a}-\mathbf{c})$, min value of different objectives is shown in Figure (d).

\section{Case 7 (at summer season)}

The effect of SD values on the Pareto solution and objective functions are plotted in Figure 9a-d, respectively, and it's clear that the min loss and voltage deviation together with minimized cost taken when $\mathrm{SD}=0.05$. In addition, $\mathrm{SD}=0.1$ is used to minimize emission. The power loss is decreased from $1033.3 \mathrm{~kW}$ to $871.2567 \mathrm{~kW}$, the voltage deviation is reduced to $4.33336 \mathrm{PU}$. The total emissions are reduced from $21,160 \mathrm{Ib} / \mathrm{h}$ to $20,175.6564 \mathrm{Ib} / \mathrm{h}$. 


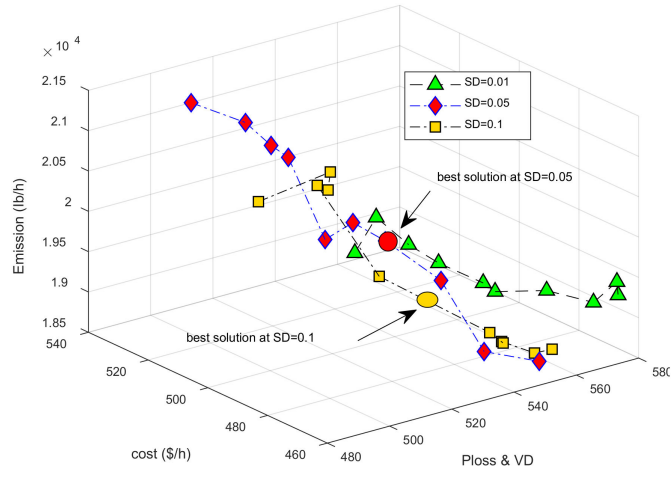

(a)

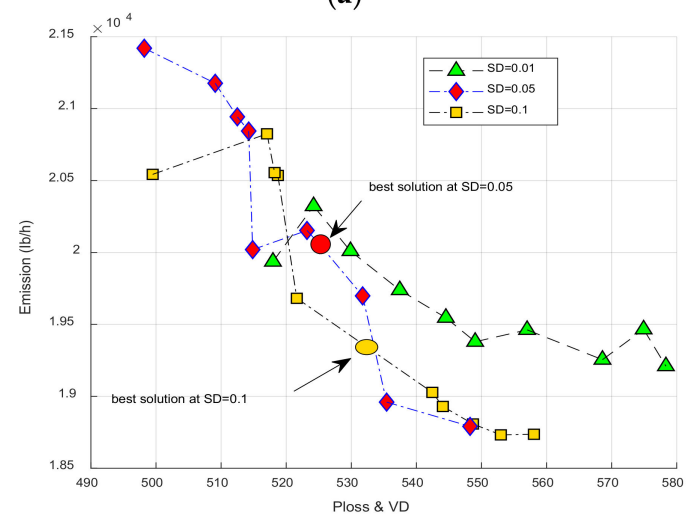

(c)

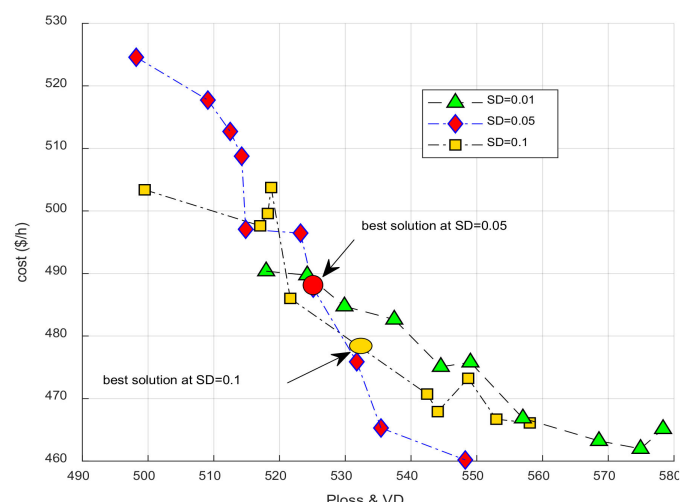

(b)
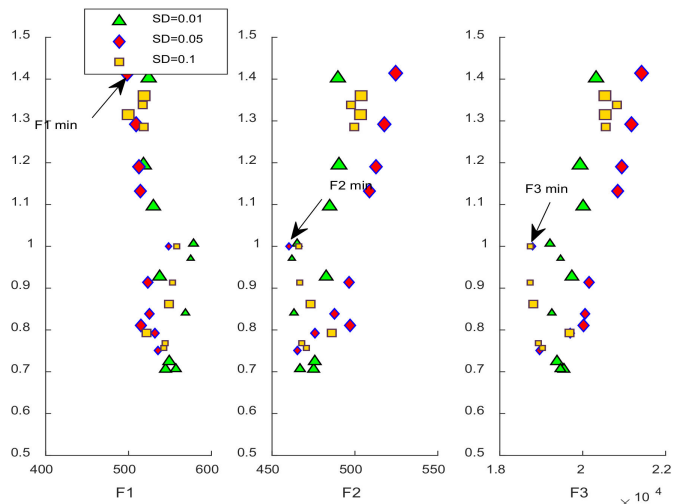

(d)

Figure 9. The performance of network under commercial load model in the summer season, best solution obtained by $\mathrm{SD}=0.1$ and $\mathrm{SD}=0.05$ are depicted in Figure $(\mathbf{a}-\mathbf{c})$, min value of different objectives is shown in Figure (d).

\section{Conclusions}

Water cycle algorithm (WCA) is used to identify the optimal allocation of distributed energy resource (DERs) in radial distribution systems for minimizing the total network power losses $\left(\mathrm{P}_{\text {losses }}\right)$, cost (C), voltage deviation (VD), and pollutant gas emissions considering different load model. The DERs and load uncertainties are considered in this study. The proposed method is tested on IEEE 118-bus radial distribution system. The simulation results show the impact of different values of standard deviation (SD) on the performance of the system. The point estimate method (PEM) is applied for modeling the solar and wind power uncertainties. The SD is variated according to load configuration, to improve the RDN performance. According to the summer load, when minimizing power losses, voltage deviation and emission for industrial load, the SD is 0.01 . When the SD is increased with small increment, the cost is reduced. In winter load, the SD equal 0.01 to minimize the energy losses, and voltage deviation, where the emission is high. When the SD is increased to 0.05 the emission is minimized. Different values of SD are obtained for each load scenario. This assures the well-known phrase "no free launch".

Author Contributions: Formal analysis, M.A.A.; Investigation, A.A.S., T.S. and A.M.H.; Methodology, A.A.S. and A.M.H.; Resources, S.A.; Software, S.A. and M.A.A.; Supervision, T.S. and A.M.H.; Visualization, S.A.; Writing-Original draft, A.A.S.; Writing-Review \& editing, T.S., M.A.A. and A.M.H. All authors have read and agreed to the published version of the manuscript.

Funding: The authors extend their appreciation to the researchers supporting project at King Saud University, Riyadh, Saudi Arabia, for funding this research work through the project number-RSP-2020/278.

Conflicts of Interest: The authors declare no conflict of interest. 


\section{Nomenclature}

\begin{tabular}{|c|c|c|c|}
\hline$A_{c}$ & Surface areas of the arrays $\left(\mathrm{m}^{2}\right)$ & $P_{M T}$ & Power produced from MT \\
\hline$\beta_{w}$ & Shape parameter & $\mathrm{P}_{g n j}$ & Active power generated by DG at bus $n_{j}$ \\
\hline$C_{c a p, i}$ & The capital cost of DG & $\mathrm{P}_{\mathrm{gnj}}^{\min }$ & $\begin{array}{l}\text { The upper limit of the real power delivered by new } \\
\text { electric units at bus nj }\end{array}$ \\
\hline$C_{F, i}$ & Cost of fuel for DG & $\mathrm{P}_{\mathrm{gnj}}^{\max }$ & $\begin{array}{l}\text { The lower limit of the real power delivered by new } \\
\text { electric units at bus nj }\end{array}$ \\
\hline$C_{F C}$ & Fuel consumption expenses in FCs $(\$ / h)$. & $P_{\text {grid }}$ & Active power from the main substation \\
\hline$C_{\text {gasFC }}$ & Natural gas price feeding the FC & $p_{\text {loss }}$ & Active power losses \\
\hline$C_{\text {gas } M T}$ & Natural gas price feeding the MT & $P_{p v}\left(s_{i}\right)$ & $\begin{array}{l}\text { Power produced from Photovoltaic system }(\mathrm{kW}) \\
\text { for the amount of irradiance s }\end{array}$ \\
\hline$C_{M T}$ & Fuel consumption expenses in MT $(\$ / h)$. & $P_{w t}$ & Power produced from WT \\
\hline$C_{O \& M, i}$ & DES operation \& maintenance cost & $p_{R}$ & Rated power of the turbine $=15 \mathrm{~kW}$. \\
\hline $\operatorname{Cost}_{D E R s, i}^{F X}$ & The initial cost of DES & PVS & Photovoltaic system \\
\hline Cost $_{D E R s, i}$ & The cost of DES connected in bus i & $Q_{\text {dnj }}$ & Reactive load power at bus $n_{j}$ \\
\hline cost $_{\text {grid }}$ & $\begin{array}{l}\text { The cost at which energy was purchased from the } \\
\text { main substation }\end{array}$ & $\mathrm{Q}_{\mathrm{gnj}}^{\min }$ & $\begin{array}{l}\text { The upper limit of the imaginary power delivered } \\
\text { by new electric units at bus } n_{j}\end{array}$ \\
\hline DERs & Distributed energy resource & $Q_{\text {gnj }}$ & $\begin{array}{l}\text { Imaginary power delivered by new electric units at } \\
\text { bus } n_{j}\end{array}$ \\
\hline$d_{\max }^{i}$ & controls the search intensity near the sea & $\mathrm{Q}_{\mathrm{gnj}}^{\max }$ & $\begin{array}{l}\text { The lower limit of the imaginary power delivered } \\
\text { by new electric units at bus nj }\end{array}$ \\
\hline FC & Full cell unit & $Q_{\text {loss }}$ & Reactive power losses \\
\hline $\mathrm{E}_{\mathrm{MTi}}$ & Emission produced from MT & $\mathrm{R}_{\mathrm{nj}}$ & Resistance of branch $n_{j}$ \\
\hline $\mathrm{E}_{\mathrm{FCi}}$ & Emission produced from FC & $\mathrm{RDN}$ & Radial distribution network \\
\hline $\mathrm{E}_{\mathrm{WTi}}$ & Emission produced from WT & $r b$ & The annual rate of benefit \\
\hline $\mathrm{E}_{\mathrm{PVi}}$ & Emission produced from PV & $s_{i}$ & Solar irradiance $\left(\mathrm{kW} / \mathrm{m}^{2}\right)$ \\
\hline $\mathrm{E}_{\text {Grid }}$ & Emission produced from main substation & $\mathrm{SO}$ & Single objective \\
\hline$K_{D E S, i}$ & DES i Capacity Factor & $\mathrm{t}$ & Number of current iterations \\
\hline$L B$ & lower bounds defined by the given problem & $T$ & DG lifetime \\
\hline MOWCA & Multi Objective Water cycle Algorithm & $\mathrm{V}_{\mathrm{i}}^{\min }$ & Minimum voltage of bus i \\
\hline $\mathrm{MO}$ & Multi-objective & $V_{i}^{1} \max$ & Maximum voltage of bus i \\
\hline MT & Micro turbine & $v_{c i}$ & Cut-in wind turbine speed \\
\hline$n_{b}$ & Total number of buses & $v_{c o}$ & Cut-off wind turbine speed $=18 \mathrm{~m} / \mathrm{s}$ \\
\hline $\mathrm{n}_{\mathrm{br}}$ & Total number of branches. & $V_{m}$ & Average wind speed for a specific location \\
\hline$N_{D E S}$ & Total number of new electrical units & $\mathrm{V}_{\mathrm{mj}}$ & Voltages of bus $\mathrm{m}_{\mathrm{j}}$ \\
\hline$N_{M T}$ & Total number of MT & $V_{\text {nj }}$ & Voltages of bus $n_{j}$ \\
\hline$N_{F C}$ & Total number of FC & $v_{r}$ & Appraised speed of the wind turbine $=3.5 \mathrm{~m} / \mathrm{s}$ \\
\hline$N_{W T}$ & Total number of WT & $V_{\text {wind }}$ & Actual wind turbine speed $=17.5 \mathrm{~m} / \mathrm{s}$ \\
\hline$N_{P V}$ & Total number of PV & rand & $\begin{array}{l}\text { an uniformly distributed random number between } \\
0 \text { and } 1\end{array}$ \\
\hline Npop & Number of population & $Y_{\text {nj }}$ & Admittance between bus $n_{i}$ and bus $m_{i}$ \\
\hline$N_{s r}$ & the summation of number ofrivers & $\eta$ & Efficiency of the PV system \\
\hline$N s_{n}$ & $\begin{array}{l}\text { the number of streams which flow to the specific } \\
\text { rivers and sea. }\end{array}$ & $\eta_{M T}$ & Efficiency of MT \\
\hline$P_{c a p, i}$ & DG capacity & $\eta_{F C}$ & Efficiency of FC \\
\hline$P_{\text {dnj }}$ & Active load power at bus $n_{j}$ & $\delta_{\mathrm{mj}}$ & Phase angle of voltage at bus $m_{j}$ \\
\hline$P_{\text {DERs,i }}$ & $\begin{array}{l}\text { The real power offered by the new electrical units } \\
\text { at bus } n_{i}\end{array}$ & $\delta_{\text {nj }}$ & Phase angle of voltage at bus $n_{j}$ \\
\hline$P_{F C}$ & Power produced from FC & $\theta_{\text {nj }}$ & Phase angle of $Y_{j}$ \\
\hline & & $\pi_{\text {grid }}$ & Energy price from the main substation \\
\hline
\end{tabular}

\section{References}

1. Alkhalaf, S.; Senjyu, T.; Saleh, A.A.; Hemeida, A.M.; Mohamed, A.A.A. A MODA and MODE comparison for optimal allocation of distributed generations with different load levels. Sustainability 2019, 11, 5323. [CrossRef]

2. Mohamed, A.A.A.; Ali, S.; Alkhalaf, S.; Senjyu, T.; Hemeida, A.M. Optimal Allocation of Hybrid Renewable Energy System by Multi-Objective Water Cycle Algorithm. Sustainability 2019, 11, 6550. [CrossRef]

3. Subramaniam, U.; Vavilapalli, S.; Padmanaban, S.; Blaabjerg, F.; Holm-Nielsen, J.B.; Almakhles, D. A Hybrid PV-Battery System for ON-Grid and OFF-Grid Applications-Controller-In-Loop Simulation Validation. Energies 2020, 13, 755. [CrossRef] 
4. Bayat, A.; Bagheri, A. Optimal active and reactive power allocation in distribution networks using a novel heuristic approach. Appl. Energy 2019, 233, 71-85. [CrossRef]

5. Kumar, S.; Mandal, K.K.; Chakraborty, N. Optimal DG placement by multi-objective opposition based chaotic differential evolution for techno-economic analysis. Appl. Soft Comput. 2019, 78, 70-83. [CrossRef]

6. El-Fergany, A. Optimal allocation of multi-type distributed generators using backtracking search optimization algorithm. Int. J. Electr. Power Energy Syst. 2015, 64, 1197-1205. [CrossRef]

7. Lasseter, R.; Akhil, A.; Marnay, C.; Stephens, J.; Dagle, J.; Guttromsom, R.; Meliopoulous, A.S.; Yinger, R.; Eto, J. Integration of distributed energy resources. In The CERTS Microgrid Concept (No. LBNL-50829); Lawrence Berkeley National Lab. (LBNL): Berkeley, CA, USA, 2002.

8. Akorede, M.F.; Hizam, H.; Pouresmaeil, E. Distributed energy resources and benefits to the environment. Renew. Sustain. Energy Rev. 2010, 14, 724-734. [CrossRef]

9. Tiwari, S.; Jain, N. Strategic Deployment of Distributed Generators Considering Feeders' Failure Rate and Customers' Load Type. AJCT 2019, 5, 1146-2350.

10. Sudabattula, S.K.; Muniswamy, K. Optimal Allocation of Photo Voltaic Arrays in Radial Distribution System with Various Load Models. Gazi Univ. J. Sci. 2018, 31, 1123-1139.

11. Yammani, C.; Prabhat, P. Reliability improvement of future microgrid with mixed load models by optimal dispatch of DGs. Int. Trans. Electr. Energy Syst. 2019, 29, e2816. [CrossRef]

12. Saha, S.; Mukherjee, V. A novel multiobjective chaotic symbiotic organisms search algorithm to solve optimal DG allocation problem in radial distribution system. Int. Trans. Electr. Energy Syst. 2019, 29, e2839. [CrossRef]

13. Naghdi, M.; Shafiyi, M.A.; Haghifam, M.R. A combined probabilistic modeling of renewable generation and system load types to determine allowable DG penetration level in distribution networks. Int. Trans. Electr. Energy Syst. 2019, 29, e2696. [CrossRef]

14. Sabaeifard, P.; Razzaghi, H.; Forouzandeh, A. Determination of vertical axis wind turbines optimal configuration through CFD simulations. In Proceedings of the International Conference on Future Environment and Energy, Singapoore, 26-28 February 2012; Volume 28, pp. 109-113.

15. Choi, N.J.; Nam, S.H.; Jeong, J.H.; Kim, K.C. Numerical study on the horizontal axis turbines arrangement in a wind farm: Effect of separation distance on the turbine aerodynamic power output. J. Wind Eng. Ind. Aerodyn. 2013, 117, 11-17. [CrossRef]

16. Cook, L.W.; Mishra, A.A.; Jarrett, J.P.; Willcox, K.E.; Iaccarino, G. Optimization under turbulence model uncertainty for aerospace design. Phys. Fluids 2019, 31, 105111. [CrossRef]

17. Mishra, A.A.; Mukhopadhaya, J.; Alonso, J.; Iaccarino, G. Design exploration and optimization under uncertainty. Phys. Fluids 2020, 32, 085106. [CrossRef]

18. Jithendranath, J.; Das, D. Scenario-based multi-objective optimisation with loadability in islanded microgrids considering load and renewable generation uncertainties. IET Renew. Power Gener. 2019, 13, 785-800.

19. Wang, S.; Luo, F.; Dong, Z.Y.; Ranzi, G. Joint planning of active distribution networks considering renewable power uncertainty. Int. J. Electr. Power Energy Syst. 2019, 110, 696-704. [CrossRef]

20. Mana, F.; Han, S.; Madeleine, G. Strategic bidding of distributed energy resources in coupled local and central markets. Sustain. Energy Grids Netw. 2020, 24, 100390.

21. Mukhopadhyay, B.; Das, D. Multi-objective dynamic and static reconfiguration with optimized allocation of PV-DG and battery energy storage system. Renew. Sust. Energ. Rev. 2020, 124, 109777. [CrossRef]

22. Recaldea, A.A.; Alvarez-Alvaradoa, M.S. Design optimization for reliability improvement in microgrids with wind-tidal—photovoltaic generation. Electr. Power Syst. Res. 2020, 188, 106540. [CrossRef]

23. Truong, K.H.; Nallagownden, P.; Elamvazuthi, I.; Vo, D.N. A Quasi-Oppositional-Chaotic Symbiotic Organisms Search algorithm for optimal allocation of DG in radial distribution networks. Appl. Soft Comput. 2020, 88, 106067. [CrossRef]

24. Hasan, K.N.; Preece, R.; Milanović, J.V. Existing approaches and trends in uncertainty modelling and probabilistic stability analysis of power systems with renewable generation. Renew. Sust. Energ. Rev. 2019, 101, 168-180. [CrossRef]

25. Home-Ortiz, J.M.; Pourakbari-Kasmaei, M.; Lehtonen, M.; Mantovani, J.R.S. Optimal location-allocation of storage devices and renewable-based DG in distribution systems. Electr. Power Syst. Res. 2019, 172, 11-21. [CrossRef]

26. Jamshidi, M.; Askarzadeh, A. Techno-economic analysis and size optimization of an off-grid hybrid photovoltaic, fuel cell and diesel generator system. Sustain. Cities Soc. 2019, 44, 310-320. [CrossRef] 
27. Karimizadeh, K.; Soleymani, S.; Faghihi, F. Microgrid utilization by optimal allocation of DG units: Game theory coalition formulation strategy and uncertainty in renewable energy resources. J. Renew. Sustain. Energy 2019, 11, 025505. [CrossRef]

28. Sarda, J.; Pandya, K. Optimal Active-Reactive Power Dispatch Considering Stochastic Behavior of Wind, Solar and Small-Hydro Generation. In Applications of Artificial Intelligence Techniques in Engineering; Springer: Singapore, 2019; pp. 255-263.

29. Veera Reddy, V.C. Optimal renewable resources placement in distribution networks by combined power loss index and whale optimization algorithms. J. Electr. Syst. Inf. Technol. 2018, 5, 175-191.

30. Awad, N.H.; Ali, M.Z.; Mallipeddi, R.; Suganthan, P.N. An efficient Differential Evolution algorithm for stochastic OPF based active-reactive power dispatch problem considering renewable generators. Appl. Soft Comput. 2019, 76, 445-458. [CrossRef]

31. Abdolahi, A.; Salehi, J.; Samadi, G.F.; Safari, A. Probabilistic multi-objective arbitrage of dispersed energy storage systems for optimal congestion management of active distribution networks including solar/wind/CHP hybrid energy system. J. Renew. Sustain. Energy 2018, 10, 045502. [CrossRef]

32. Zhang, L.; Yang, H.; Lv, J.; Liu, Y.; Tang, W. Multiobjective Optimization Approach for Coordinating Different DG from Distribution Network Operator; Journal of Electrical and Computer Engineering: London, UK, 2018.

33. Wu, R.; Sansavini, G. Integrating reliability and resilience to support the transition from passive distribution grids to islanding microgrids. Appl. Energy 2020, 272, 115254. [CrossRef]

34. Karimi, B.H.; Bahmani, R.; Jadid, S.; Makui, A. Dynamic transactive energy in multi-microgrid systems considering independence performance index: A multi-objective optimization framework. Int. J. Electr. Power Energy Syst. 2012, 126, 106563. [CrossRef]

35. Ghasemi, M.; Ghavidel, S.; Ghanbarian, M.M.; Gitizadeh, M. Multi-objective optimal electric power planning in the power system using Gaussian bare-bones imperialist competitive algorithm. Inf. Sci. 2015, 294, $286-304$. [CrossRef]

36. Esmaeili, M.; Sedighizadeh, M.; Esmaili, M. Multi-objective optimal reconfiguration and DG (Distributed Generation) power allocation in distribution networks using Big Bang-Big Crunch algorithm considering load uncertainty. Energy 2016, 103, 86-99. [CrossRef]

37. Aghajani, G.R.; Shayanfar, H.A. ShayeghiH Demand side management in a smart micro-grid in the presence of renewable generation and demand response. Energy 2017, 126, 622-637. [CrossRef]

38. Kefayat, M.; Ara, A.L.; Niaki, S.N. A hybrid of ant colony optimization and artificial bee colony algorithm for probabilistic optimal placement and sizing of distributed energy resources. Energy Convers Manag. 2015, 92, 149-161. [CrossRef]

39. Jabr, R.A. Adjustable robust OPF with renewable energy sources. IEEE Trans Power Syst. 2013, 28, 4742-4751. [CrossRef]

40. Alavi, S.A.; Ahmadian, A.; Aliakbar-Golkar, M. Optimal probabilistic energy management in a typical micro-grid based-on robust optimization and point estimate method. Energy Convers Manag. 2015, 95, 314-325. [CrossRef]

41. Sadollah, A.; Eskandar, H.; Kim, J.H. Water cycle algorithm for solving constrained multi-objective optimization problems. Appl. Soft Comput. 2015, 27, 279-298. [CrossRef]

42. ElAzab HA, I.; Swief, R.A.; El-Amary, N.H.; Temraz, H.K. Unit commitment towards decarbonized network facing fixed and stochastic resources applying water cycle optimization. Energies 2018, 11, 1140. [CrossRef]

43. Dong, Z.; Fu, Z.; Zhang, L. An improved TS algorithm for loss-minimum reconfiguration in large-scale distribution systems. Electr. Power Syst. Res. 2007, 77, 685-694.

44. Zhou, J.; Ayhan, B.; Kwan, C.; Liang, S.; Lee, W.J. High-Performance Arching-Fault Location in Distribution Networks. IEEE Trans. Ind. Appl. 2012, 48, 1107-1114.

Publisher's Note: MDPI stays neutral with regard to jurisdictional claims in published maps and institutional affiliations. 